\title{
UC-NRLF
}

+B 27〕 ? 9 



Digitized by the Internet Archive in 2007 with funding from Microsoft Corporation 
Thames AND TweEd. 



\section{THAMES AND TWEED.}

BY

\section{GEORGE ROOPER,}

AUTHOR OF "FLOOD, FIELD, AND FOREST:"

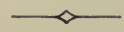

CASSELL, PETTER, AND GALPIN, LONDON AND NEW YORK. 
LONDON :

PRINTED BY CASSELL, PETTER, AND GALPIN, BELLE SAUVAGR WORKS, E.C. 


\section{THAMES AND TWEED.}

\section{INTRODUCTORY.}

IT is my belief that, when dominion was given to man over the beasts of the field, the birds of the air, and the fishes of the sea, certain tribes or families of the two former were more especially destined for his use and sustenance, and were endued with the instinct of domestication, which rendered them subservient to his will, reliant on him for their support and maintenance, and submissive in at least some measure to his requirements for animal food. Of some beasts, then as now, both the wild and the tame type existed; of others the wild only, or the tame only. So with birds: there were tame birds and wild birds, and some which, being neither tame nor wild, were capable of sufficient domestication to keep them within the reach of man, although they might not, like Mrs Partington's ducks, "come and be killed." I think that no one 
who, putting aside prejudice and long-received opinion, gives the matter his serious consideration, can doubt this.*

As to fish, the case was altogether different; it necessarily was at the Flood. There was no bond of union or sympathy between them and man, no natural dependence; and his dominion over them was strictly limited to his power of exercising it: the fear of him and the dread of him were innate in the fish, but neither love nor craving for protection, nor voluntary submission to his will.

From very early, if not from the earliest times, men seem to have enjoyed the pursuit and capture of fish. We find angling in our oldest written records, in the perhaps still more ancient records of the Egyptians. Job, in the earliest of our books (unless the Pentateuch be still earlier), is asked, "Canst thou draw out Leviathan with a hook, or his tongue with a cord which thou lettest down?" Cleopatra, we are told, cajoled Mark Antony,

* Abel was a keeper of sheep - of domesticated sheep-such sheep as the Eastern shepherd has, ever since the actions of man were recorded, led forth to the green pastures; not of the Aoudad, the wild type of the race, the active, unsubdued creature, still found in numbers on Ararat and other mountains of the East. Job possessed cattle and asses, but surely neither the bison nor the buffalo, the quagga nor the zebra: untamed and untamable they then wereuntamed and untamable they continue to the present day. 
"inter alia," by making her slaves dive and affix live fish to his hook, as they sat and enjoyed the sport of angling together. Angling was an amusement in which her very remote Egyptian predecessors appear to have delighted, and natives of high rank are depicted as catching fish with a line. I am afraid of appearing too pedantic, or I might quote Oppian, a Greek writer who flourished about A.D. I 7O, and wrote a poem in five books upon fish and fishing ; or Homer, who lived a thousand years before him, and who more than once distinctly refers to the art of angling : the monster Scylla is represented as catching dolphins.

But I need not insist further: angling must be admitted to be one of the most ancient, and I claim for it the credit of being the most scientific, the most absorbing, and the most satisfying amusement that can be followed in the way of sport. Neither is the fascination it exercises over its votaries of an evanescent character. Men "lose their nerve" and give up hunting; they lack strength for walking; their eyesight fails and they give up shooting; rowing, after a certain time of life, becomes irksome; cricket and football are out of the question: but who ever gave up fishing? or has heard of any one giving up fishing, so long as he could handle a rod, or hobble along the bank, or even sic in a 
boat? There is a well-known character at St Boswell's, a man of humble birth, totally blind, who, attended by his dog, gropes his way daily to the Tweed, and there angles, not unsuccessfully, for trout, with a fly. $\mathrm{He}$ is a poor man, and has neither help nor guide beyond what casual sympathy may bestow; yet except once, when he caught his dog, who, after ten minutes' exciting play, broke his tackle, and left him groaning over the supposed loss of a huge salmon, I never heard of his coming to grief. Yes! fishing is a noble art, an absorbing occupation, and one to which a man of high intellect may without shame or scruple give himself up. Its pursuit leads the angler into the most beautiful scenery, at the loveliest time of the year, and the pleasantest hours of the day; it is not so absorbing as to preclude the contemplation of the beauties of nature or to exclude reflection; it is a sufficiently active employment for health and exercise, without necessitating the more boisterous efforts of the chase or the harder labour of shooting. It is a pursuit, the pleasure of which increases with its practice-it "grows by what it feeds on"-increasing rather than diminishing with age, while the skill and knowledge gained by long experience more than compensate for the absence of youthful strength and vigour. Were I a fish, I 
should pray to be defended from the attack of an 'old fisherman.'

With respect to the practical part of the art, of which I purpose to treat in the following pages, I am well aware that there are scores of fishermen with ten times my experience, and ten times my skill, who might write upon the subject; but they do not. I do not write for such, except that they, as critics, may correct any error of mine, and, exposing it in a friendly spirit, add the result of their own experience or observation. In a nation of blind men a one-eyed man is king, according to the French adage; and on that principle I have jotted down such precepts and such information as appear to me, after a long, if not extensive, practice of the art of angling, to be best worth noting : and, craving the indulgence of the more experienced, I venture to commend the following pages to the perusal of the younger and less-experienced followers of the noble and most scientific pursuit which can be classed under the head of sporting. 


\section{PRELIM I N A RY.}

FISHERMEN are generally methodical, and it is in deference to the requisitions of method that I "begin at the beginning," and offer a very few preliminary hints on the subjects of dress, rods, tackle, \&c. There is nothing particularly new or important or interesting in what I offer; but, as the result of some considerable experience and observation, it may be found useful to some of my readers. The practised fisherman will, of course, skip the chapter, and the unpractised one will do so or not as he thinks proper. I have advisedly made my observations as brief as possible. I need hardly say that they might have been spun out to any conceivable extent, and that without any especial strain on either my inventive powers or my memory.

Dress. - The fisherman's dress is by no means an unimportant matter. Bright colours or white must be avoided. Let your person be arrayed "integumentis nigris vel obfuscis," as the Oxford 
statutes run. Wear a flannel shirt and a lowcrowned hat, two pairs of socks at least under your wading stockings, and one pair over. Your shoes should be made of good, sound, country leather, the sole as thick as is compatible with comfortable walking, and studded with an abundance of the roughest, ugliest nails you can get(wading shoes are not intended to walk on Turkey carpets with); grease them thoroughly while wet, which will prevent them becoming hard or cracking; but take care that the grease do not touch the stockings themselves. The more flannel you have about you the better; and your waterproof garments, however impervious to water, should by no means be air-tight: it is as bad, nay worse, to be wet from within as from without.

Rods.-Of the manufacture of rods I shall say nothing. I recommend the young fisherman to go to a first-rate shop in London, Dublin, or Edinburgh, and pay a fair price; and I will venture to say that, if the desired result be not obtained, the fault will not be in the tool, but in the workman. For bottom-fishing, trolling, and spinning, no rods in the world excel those made in London. As to fly-fishing rods, opinions differ. The English-made rods are generally stiff, the Irish are generally the reverse; but Irish 
makers have the advantage, inasmuch as they can make a stiff rod, but English makers generally fail in their pliable ones. English rods, too, from the difference in wages and rent, are necessarily more expensive than Irish. Rods vary in price, from five shillings for bottom-fishing, to five pounds for salmon-fishing. The worst in my possession cost me the latter amount. Great difference of opinion exists as to the respective merits of the stiff and the limber salmon-rod. I prefer the latter, but, as usual, there is much to be said on both sides. The stiffer the rod, the easier it is to throw with, and the less the chance of whipping off the fly. A stiff rod, too, picks the fly more readily off the water, and, deftly handled, will throw a heavy line in the teeth of a Nor'-wester, "bite he never so rudely." But then it seldom happens that the fisherman is compelled to cast in the teeth of the wind. Streams-trout and salmon streams especially-turn and wind, and bend and double, and present all manner of faces to the wind. If one pool will not fish, another will ; if one stream run counter, the next will flow fair: a side wind, as in sailing, can always be made serviceable; indeed it is greatly preferable, to my thinking, for casting, whatever it may be for sailing, to one directly astern. The "gentle art" is not 
to be pursued by rough, defiant methods, but by humouring, as it were, and taking advantage of the chances and changes which natural causes, bent to the desired purposes, present. Although the proper handling of the springy rod, such as is ordinarily used in Ireland, is far, very far, more difficult to attain to, the result is well worth all the trouble, and all the expense in loss of flies, of arriving at it. Of course, if you wish, having hooked a fish, to haul him out, as it were, "by the hair of the head," the object is much better attained by means of a stiff rod than a pliable one ; and when fish are rising freely and taking the fly greedily, a much larger number may be taken within a given time than can possibly be brought to basket with a limber one; but it is very rarely that fish are in this accommodating humour, and a far larger proportion of those hooked are killed with a pliant rod. Even were it otherwise, the balance, in my mind, would still be greatly in its favour. The sport shown by the fish is infinitely greater in the one case than in the other. The angler's object is not simply to kill a quantity of fish; were it so, the net would effect the object more readily; and, on the whole, having regard to the conscious pride of skill and the pleasure in exercising it, as well as to the result, I recommend young fishermen to 
adopt the use of a limber, springy, spliced rod, in preference to a stiff-jointed one. He will find that, having once overcome the little propensity the rod at first evinces for sending it "to grass," the fly drops upon the water in a far more satisfactory manner. It floats out, as it were, and, hovering for a moment when at its utmost stretch, alights like thistledown upon the surface of the water, instead of hitting it with the force of a pebble or the preliminary hailstone of a summer storm. If, in the excitement of the moment, you strike somewhat too strongly, the hook is not torn from its hold; if the fish jump, the rod yields to the strain; if chance or carelessness slacken the hold, the pressure is merely abated, not removed. Even in unpractised hands, a fish finds far less chance of escape, for the limber rod yields to each struggle, and for the fish to obtain a dead pull is impossible. There is something, too, so graceful in the mere use, as well as in the detailed play, of a pliant rod: no exertion, hardly any strength, is required; the rod itself appears, as though instinct with life, to have shot forth the "imponderable" fly into boundless space. This, I need hardly say, is not the work of the top joint, or of any other joint: the rod plays and works "homogeneously," to use a long word, from the butt to the tip. The assumed 
trouble of putting up and taking down a spliced rod is purely imaginary, and simply betrays want of experience in those who advance it as an objection. I can tie my splice at any time in less than a mirute; and whether I remain on the river a day, a week, a month, or a season, it would never occur to me to untie it until I go away.

Reels.-Of the means and appliances necessary for fishing, there are none of greater importance than the reel, and none in which, happily, greater perfection in the manufacture has been attained. Excepting multipliers, which are things of a bygone age, no bad reels are now made. Of course they bear the names of their vendors, but, like guns and gun-locks, they are, I take it, generally made at Birmingham, and the difference in quality is fairly represented by the difference in price, which ranges from two shillings to two pounds. The larger the cylinder the better, and where intended to carry an unusual length of line, the increase in size should be rather in the direction of depth than breadth. The handle, if of the ordinary formation, should stand clear of the side, and the edges should be bevelled off, so that in the event of its being caught, the line may not be cut upon it. By far the best principle, however, was invented by my friend Captain H. L., of Dublin, some twenty years since, 
but unfortunately not patented. It is now tolerably common in most shops,- - the peculiarity being, that the handle, consisting of a bone or ivory cone, is fastened to the circular plate which turns the cylinder, so that, should the line catch, it slips readily off. I have in my possession the first reel that ever was made upon this principle, and, though rather wheezy, it is still a very useful implement. One or two cogged wheels are essential to the true working, and these create that glorious "whirr" which strikes so gladly on the fisherman's nerves when his fish is running out line. Irish reels are generally attached to the rod by means of a long spike, terminating in a screw that passes through the butt, a button being screwed on to the opposite side; but the ordinary English mode of sliding rings is, I think, preferable. Whichever mode is adopted, the reel should be fixed with its handle towards the fisherman's left hand. When a fish is struck, the rod must be at once turned upwards, the line and the weight of the fish in consequence resting upon the rod itself, instead of upon the rings; the handle will then, of course, be in its proper place on the fisherman's right hand. Rings, by the way, are rarely of sufficient size or in sufficient number. Eighteen may with advantage be attached to a salmon-rod, and the smallest 
should be of sufficient size to allow of the line running through them with perfect ease.

Hooks. - The principal manufactories of hooks are at Redditch, Kendal, Carlisle, Kirby, and Limerick. I question whether there is any difference in quality, though of course fishermen will have their predilections on the subject. Hooks are made in sizes, numbered from I to I2,-the English ones commencing with No. I, the Limerick with No. 12, as the smallest. The "sneck-bend" is the most approved form for angling purposes. In this the barbed point is notexactly in the same plane with the shank, and, in consequence, more likely to strike into the fish's mouth. A much longer shank is required for fly-tying than for angling purposes, and it is of much greater importance to secure a really good and well-tempered hook.

Flies.-Of flies, so called, the shape, size, and colour are diversified beyond measure, limited, in fact, only by the fancy of their maker. For salmonfishing, I advise using on all occasions local flies: they may not be so taking to your eye, but you are not a salmon; the "rule of thumb" is generally found infallible, and the experience of generations of fishermen has proved what particular fly is most captivating in each particular water. I think that harmony in colours has more to 
do with success than any other quality; and in looking. at the gorgeous and costly flies got up in London shops, it must not be forgotten that if the fly swim truly and well-and unless it does so the fish will not rise at it-only the breast or lower portion is presented to the fish's ken. I have seen in books of Natural History, the authors of which think it necessary to assign a patent cause for every natural effect, that the gorgeous plumage of the kingfisher is given to him for the purpose of attracting the fish towards him. Yet this gorgeous plumage is all on the bird's back, and that presented to his innocent victims is of the most unpretending and unobtrusive character. Seen through the watery medium, all colours are blended into one, more or less partaking of the predominant one, red, yellow, or blue. Such will be the colours, when exposed to the air, of numerous marine insects and molluscs on which the salmon feeds in the tideways, and for which, if played in the jerking mode peculiar to marine insects, he probably mistakes the fly. It is a beautiful and most useful art, that of tying flies, and one in which, at an early period of my life, I acquired some slight skill ; but the limits of my leisure did not admit of my attaining to any proficiency in it: and again, at the risk of being considered a lukewarm follower of the 
craft, I counsel my readers to repair to the best shops in the immediate vicinity of the river they mean to fish, or to purchase from the professional fishermen who may haunt the water.

In salmon-fishing one fly only is used. In a recent work "two or three" are recommended, but the suggestion seems to argue some want of experience. THREE flies are never used in salmonfishing, for obvious reasons. Even with two flies up, the danger is great. Whether in lake or river, there must be banks, rocks, logs, or weeds, upon which a hooked salmon may hitch the disengaged fly; and should you-which is quite probablehook a second fish while playing the first, you might as well hope to hold two bulls tied together by the tails as two salmon so coupled. You would sing with Macheath-

"How happy could I be with either!"

But, rely upon it, both one and "t'other dear charmer" would soon be "away."

Lines.-The best lines are made of silk and hair, in what proportions I am ignorant. They are sold in all shops, from three halfpence to three pence a yard, according to the conscience of the vendor. "Prepared" lines, as they are called-that is, lines coated with a preparation of wax and oil -are excellent for trolling and spinning purposes, 
but are not very commonly used for fly-fishing. About eighty yards I consider sufficient for a salmon-line-perhaps a hundred may be better, as allowing for waste; and, of course, one may meet with fish endowed with extraordinary running powers, or the fisherman may be in positions where a very long line is essential; but in my personal experience I have never had eighty yards of line entirely run off my reel, though, upon two occasions-one on the Makerstoun water on Tweed, and one at Ballyshannon on the Erne-only a few feet out of that quantity were left on my reel. The line, whatever its length, should be thickest at the end attached to the reel, and gradually taper towards the casting-line.

Casting-Lines.-The casting-line, like the line itself, should taper from its base, commencing with two or three plaits, and terminating in at least three feet of good, round, sound, single gut. Machines may be bought for the manufacture of casting-lines, as for cartridges, meerschaum pipes, or anything else, with full instructions gratis; but you will buy far better than you can make-at least I can-and cheaper too. The gut should be stained before it is made up-blue, or green, or coffee-colour, anything but black or white. Un- 
stained gut would doubtless be the best if it would retain its transparency; but it will not. When soaked it becomes opaque and white-a colour of all others the most visible in the water.

Fly-Books.-Fly-books, like shooting-coats, are generally made too small. They should be as large as can conveniently be carried in your pocket. Besides flies, your book should contain a skein of fine silk, some strands of gut, a piece of prepared wax, a pair of scissors, half-a-dozen spare casting lines, and some Nottingham twist (with which to splice a broken top). Two or three leaves of some soft, spongy substance-I hardly know what, but not flannel-should be inserted, wherein to stick used flies to dry. Flannel is too tough, and is apt to retain an inconvenient hold on the hook, should the barb penetrate it. Bottomfishers' books must, in addition, be furnished with plummet, split-shot, spare lines, disgorger, floats, and quill caps. I take for granted that no fisherman ever goes out without a good knife, a piece of string, a cork-screw, and a button-hook in his pocket.

Landing-net.-The landing-net for trout should be light and deep, and manufactured of fine but strong twine. When carried by an attendant, the handle can hardly be too long, in reason; 
but, when carried by the fisherman, two feet may be quite long enough. It should be stuck by means of a flat piece of metal into a belt; and $\mathrm{Mr}$ Armstrong, of Oxford Street, has invented, or at any rate sells, a hinge fitted with a screw at each end, which enables the net to hang doubled up out of the fisherman's way, and is fixed without difficulty in its proper position by a springcatch. The invention, whoever may claim it, is an admirable one.

For salmon, the net cannot, in reason or out, be too long, or too large, or too deep, or too strong, so long as your attendant can readily use it. The hoop should be iron, three feet across, the net five feet deep, and of the strongest material, the handle eight or nine feet in length. After the capture of each fish the net should be thoroughly washed; there is a sort of slime, especially on the autumn fish, which, if not removed, rots the net very rapidly, and a salmon will go through a rotten net like harlequin through a paper hoop.

Gaff.-The gaff should be made of well-tempered steel, not too large or too small, about the size of a small butcher's-hook. There should be an elbow or curve in the back, which gives a better hold. A barbed gaff is an abomination, a poaching implement,-a sense of the enormous mischief per- 
petrated by which I have in vain endeavoured to instil into $\mathrm{Mr}$ Frank Buckland's mind. It is the main instrument of poaching in the Welsh rivers, and without it the poacher's occupation would be gone, A barbed gaff spoils the fish, and no true sportsman would think of using one. "Delenda est." The handle of the gaff should be four feet long, not too heavy or stiff, and in some degree elastic; the great secret in using it is to pass it under the fish, not to be in a hurry, to make sure of your stroke, and never to relax your hold.

Bag and Basket.-Waterproof bags have come into fashion of late years. They are most useful articles, but should supplement, and not supersede, the basket. They are essentially nasty things as receptacles for fish; the fish soon spoil, and they impart a vengeful smell, which water will not wash away. The best bags I know are made by $\mathrm{Mr}$ Woolgar of Ludgate Hill. They have, or ought to have, three smaller pockets inside, in which to deposit your pipe and tobacco, cigar-case, flask, knife, note-book, and other trifles; the bag itself accommodating your lunch, your sketch-book, a copy of "Thames and Tweed," "Flood, Field, and Forest," or some other readable book, wherewith to wile away any non-fishing hours of the day.

The fisherman's basket requires no special de- 
scription-do not have it too large. It is astonishing how many pounds of trout will pack in a small basket; and salmon are always worth carrying by hand.

Trout-flies are, to some extent, like salmon-flies, local ; but there are certain "standard" flies, with which, in two sizes, every angler's fishing-book should be furnished. These are the blue dun, the hare's ear, the March brown, the Marlow buzz (Welsh cock-y-bondhu), the black gnat, and the palmers, black, brown, and red.

Flies are assumed to represent not only the insects so called, but also beetles, and caterpillars. The latter are known as palmers-why, I cannot say, excepting, perhaps, that they are both "crawling beggars." Beetles, of which the "Welsh button" is one of the most killing, are generally used on hot days. The winged flies are best on a windy day, when they may be assumed to have been blown into the water. Flies tied without wings are called "buzz," and are supposed to represent the drowned insect. Duns are the immature, spinners the perfect insect.

Throwing the Fly.-Reading and writing, Dogberry says, come by nature, and in the main Dogberry was right. No written or oral instruction can make a horseman, a sportsman, or a fisherman. 
Each one, like "Poeta," "nascitur, non fit." Still, some general rules may be laid down for the guidance of the tiro. The grand rule to be observed is-to make your rod do the work. To "keep a dog and bark yourself" is proverbially foolish; and, having acquired an implement so beautifully adapted for its purpose as a well-made rod, it is absurd not to make full use of it. Strength-I mean muscular power-is not necessary. I do not say that a strong man, "cateris paribus," will not throw a better line than a weak one; but strength is not "the one thing needful."

He whose
"Rod was made of a sturdy oak,
His line a cable that ne'er broke,
Whose hook was baited with a dragon's tail,
Who sat on a rock and bobbed for a whale,"

could not have thrown ten yards of line if his life depended on it.

As I have said, let your rod do the work. Begin with a short line without a hook, practise on the land till you have got the line, to some extent, under command, and when you commence real fishing, do not attempt too much. Far more fish will be caught by a short line, well thrown, than a long one, badly thrown; indeed, it will be a miracle if the latter ever succeed. Theoretically 
your line must stretch backwards as far as it is intended to be cast forward, and ample time must be afforded for the fly to reach the furthest point before you return it, or it will be whipped off.

Practice, however, will greatly modify the first part of this rule, and enable you to get your line out where rocks or trees are close behind your back. Let the beginner avoid all difficulties of the sort, and simply essay to throw the line clear and well away from him. This he will do by a plain upand-down stroke, the spring of the upper portion of the rod being brought into play. The knack once acquired, any degree of excellence may be obtained by practice, and, so far as I know, by no other means. Teaching is of no avail, and I, therefore, abstain from attempting it. 


\section{I. \\ Thames.

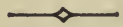 \\ THE GUDGEON.}

I BEGIN with the gudgeon. Why? Because, as a much-respected friend of mine, formerly a tradesman, remarked, in explanation of his refusal to visit a captain on half-pay, who, covered with scars and glory, supported his rank, his wife, and four children on $£ 300$ a year- "One must draw the line somewhere." I draw mine at the gudgeon, otherwise I would fain give the little urchins, who sometimes fish for minnows and fry in the Serpentine with crooked pins, some hints for their guidance. Whatever is worth doing at all, is worth doing well, and the pin might be crooked more artistically, more scientifically; the broken match which does duty for a float might-but I abstain. One dogma only will I enunciate, and that more for the benefit of the owners of aquaria than that of the little Arabs. If you wish to transport your min- 
nows, especially in hot weather, from one place to another, fill the bottle half full of water, insert the fish, and cork it tightly down. Of course, this is all against philosophy, analogy, and so forth, but it is the true method. I have proved it. Now for the gudgeon.

Gudgeon-fishing may be considered as the very accidence of the grammar of fishing, and, unless with the minnows I have referred to, I could hardly commence lower in the scale than with the phase of Thames angling known as "gudgeon-fishing." Reader! do not curl your lip in scorn! Thames angler! dread not a sneer! We have heard your craft contemned, we have known it mentioned with deprecatory and faint praise, as though it required an excuse. In our estimation, nothing of the sort holds place ; we are fishermen-pure and simple. As a learned judge said to his brother judge at a bar-dinner,- "No, brother; not bad port wine: there is no bad port wine; some port is better than other-but there is no bad port wine." So say we of fishing: some fishing is better than other, but there is no bad fishing; and we would rather angle for a stickleback in a ditch, or a newt in a tank, than not angle at all. There are degrees, too, in gudgeon-fishing. Every man, no doubt, can catch gudgeons; but one will catch a 
hundred, while another catches a score-one will catch a score, while another catches a dozen.

But before we approach the subject of catching him, let us consider what he is. The gudgeon is one of the "Cyprinide"-a branch of the great carp family, which, with a few exceptions, populate the Thames. His scientific name is "Gobio"-a word originally applied to any fish of small value"Gobio fuviatilis" - and he enjoys, in common with most other fishes-therein contrasting favourably with birds - the advantage of having only one name, English or Latin. The appearance of the gudgeon is too well known to require description, but it may be remarked that, like his cousin the barbel, he is gifted with two small "barbules" pendant from the angle on each side of his mouth. The exact purpose of these appendages it is difficult to assign, but no doubt they act in some way as feelers, like the whiskers of a cat, and assist the fish, which is essentially a bottom-feeder, in detecting its prey in the gravel among which it loves to "routle."

In fishing for the gudgeon, a lengthy rod is unnecessary; it is naturally a bold fish, greedy, and, like most others which feed in shoals, ever anxious to snatch the worm from its neighbour's mouth, and almost proverbially easy of capture. The gudgeon is not, in fact, more stupid than other fish; 
but, swimming in immense shoals, and distributed over the greater portion of the rivers it inhabits, there are always young and inexperienced fish ready to snap at the bait offered to them. There is no doubt, however, that gudgeons, like all other fish, have learned wisdom from experience, and the numbers formerly taken-sixty in an hour was no unusual quantity - are now unheard of.

To fish for gudgeon, the depth of water should be first accurately plumbed, and the bait-a small red worm-allowed actually to trail upon the ground, being carried down by the force of the stream, acting on a sufficiently-leaded quill float. The line, as in every description of angling, should be kept well out of the water-not so tight as to impede the swimming of the float, but never so loose as to allow an appreciable interval of time between the strike and its effect. In rapid streams the strike can hardly be too quickly made, but in slower ones, the float should be allowed to disappear beneath the surface; and it must be ever borne in mind that the strike, to be effective, must be made while the fish is running from you. If the float has begun to rise, the slight turn of the wrist which effects the strike is made in vain. A rather oblique direction, with reference to the assumed position of the fish, we have generally found the best 
It is customary for the puntsman to use a long, heavy iron rake, with which he disturbs the bed of the stream, thereby exposing the myriad of insects and partially-developed forms of insect life on which the gudgeons feed, and towards which they, with small perch, ruffs, young barbel, and other fishes, eagerly rush. For ourselves, we, upon the principle of " nec Deus intersit," \&c., prefer trying a few swims before we rake. It is easy to see the shoals of fish where they exist, and the bottom being level and clear of weeds, to make your pitch accordingly. When the appetite of what may be called your invited guests is to some extent satiated, it is time enough to use the rake, to call distant friends and strangers to the feast.

This fish is in season from June to September, after which they retire to the deep holes, and are rarely, if ever, taken-remaining probably in a semi-torpid state throughout the winter. It spawns early in the season - the end of March or beginning of April.

The gudgeon, properly dressed-fried in oil, or abundance of lard, we consider the best mode-is a dish worthy of an epicure, and a few hours may occasionally be spent in capturing him with both pleasure and profit. 


\section{THE ROACH.}

THE roach is a far-away cousin of the gudgeon, another of the great family of Cyprinida, which ought to be canonised as affording, at their proper cost, the greatest amount of sport to the greatest number of anglers. Laugh and jeer as ye may, ye fishers for trout and salmon! we maintain that there is more delicacy of touch, more pride of art, more artistic skill in roach-fishing than in any other sort of angling whatever. The roach is not naturally a shy fish; he is, as beseems his somewhat aldermanic figure and the amplitude of his white waistcoat, a free liver, and ready to take at any time almost any bait that may be offered to him. In lakes, and ponds, and unfished waters, the roach may be taken in any number by the rudest devices; but in the Thames, where generations of fishermen have continually exercised their craft at the expense of successive shoals of roach, he has become shy and wary to a degree; and though we read in "Land and Water" daily records, on the respected authority of W. H. Brougham, of twelve dozen and upwards killed in a day, we well know that the numbers, like the "fifty 
thousand additional lamps" in the long-extinct Vauxhall Gardens, are rarely counted, or rather counted with rare liberality; at all events, they consist principally of the youthful fry, all inexperienced in the wicked devices of the angler. "Non cuivis contingit"-it is not every one who can fill the well of his punt with really good roach, each from half a pound to a pound and a half in weight, in a day's angling. The fisherman who can do this in ordinary circumstances may be sneered at by the mighty salmon-fisher, but give him the same opportunity, and rely upon it he will make good use of it!

The roach affects deep running, but not rapid water; he feeds near, but not on, the bottom; and, after plumbing, the bait should be regulated so as to travel two or three inches from the bottom. The roach may be fished for either from a punt or from the shore, and to the bankfisher there is no inhabitant of the Thames that affords such constant and unintermittent sport. The rod for this purpose is made of bamboo, eighteen or twenty feet in length, the last joint of the butt end being readily removable to facilitate the landing of the hooked fish. When a reel is used, it must be carried in the pocket, but a reel is generally dispensed with, the length of the 
rod admitting of sufficient line wherewith to play a fish so averse to locomotion as is the roach.

The bank-fisher is generally a character in his way, and enthusiastic in the art; he carries with him a large flag-basket, containing, besides his pipe and his luncheon, all the implements of his craft; he has, too, a camp-stool and a forked stick on which his long rod rests. Patient and contemplative, like his prototype the heron, he sits through the long day watching his well-balanced float, and not unfrequently carries home to his sympathetic and admiring family a considerable weight of fish.

"Pleasant is the fisher's life

By the waters streaming."

But our business is not with him.

The roach is the king of fishes to the genuine punt-fisher. And here we may describe the operation of "fixing the punt," which is by no means so simple or easy as it may appear to the uninitiated. It should be stated that roachfishing differs from gudgeon-fishing in this, that while in the latter a constant change of place is desirable-the fish going off their feed after some twenty minutes or half an hour, and always taking best in new and unaccustomed places -the former seem to affect the same localities continuously. The longer you fish and the more 
ground-bait you throw in, as a rule, the more roach you will take. With gudgeons the converse will be found to be the case. Having arrived at your swim, a known resort of the roach, taking one "ripeck" in hand, and leaning forwards up-stream as far as you can reach, bringing the iron-shod end almost under the boat, you proceed by a wriggling motion of the arms, requiring some considerable strength and more skill, to fix it in the hard bottom, at an angle of something like fortyfive against the stream; then using the fixed pole as a lever, you swing or pass the boat gradually round, walking with the other ripeck to the opposite end, your companion in the meantime tying the rope to that already fixed, and then finishing the operation by tying your own. There is some art even in the simple operation of fastening the ropes. If tied too closely the punt will lift the poles, if not closely enough, its working, from the action of the stream, will loosen the hold on the bottom. The string should be cross-gartered, Malvolio-fashion, and fastened some two feet above the gunwale with a simple half-hitch.

Your punt being properly pitched, the next operation is to manufacture ground-bait, the materials for which-clay, bran, soaked bread, and a few scalded greaves-it is assumed, have been pre- 
viously provided. These materials are kneaded into round balls somewhat bigger than one's fist, the object being to amalgamate as much bread, and more essentially bran, as the clay will carry to the bottom. Boys delight in the essentially nasty operation of manufacturing ground-bait, and casting the balls into the swim. The action of the water disintegrates the ball, and the floating particles pass down the stream, offering a lure to the fish, which they follow up from great distances. The ground-bait should be thrown in at intervals-now and again a lump-not continuously, or it is possible that the fish may make their dinner off what is intended merely as a whet to the appetite.

The rod required for roach-fishing from a punt is not nearly so long as that used from the shore, the bottom joint of which, as has been said, is generally taken off before the fish is landed; but as compared with that used for gudgeons it should be lengthysay thirteen or fourteen feet. It must be tolerably stiff, too, to ensure rapid striking, which is absolutely essential in roach-fishing. The line should be fine, the reel true, and the bottom of the very finest gut, or, which is generally preferred by the accomplished angler, of single hair ; the float of cork, long, large, and tapering, heavily shotted with numerous fine shot, until it swim with not more than half an inch 
above the surface : the shot should be about a foot from the hook, a single one being affixed three inches above it to keep it in its proper place. The object of the powerful, well-balanced float with a quantity of shot is to insure the rapid sinking of the bait, so as to get the full advantage of the swim, and at the same time to indicate the slightest possible bite. The line after each swim should be brought back quite close to the gunwale of the boat, and the bait occasionally examined to see that it has not become dead and sodden.

The strike must be instantaneous, or you will never catch your fish; and it is well, whether you observe a bite or not, invariably to strike at the end of your swim, as a fish may be, and frequently is, at that moment testing the quality of your bait, which he is certain to eject, with that marvellous and unexplained power which all fish possess, some twelve inches from him, the moment he becomes aware that there is something unwholesome in the just-coveted dainty. The line as well as the rod must be much longer than for the gudgeon, the roach being the shyer fish, and not inclined to feed so near the boat; but it is far more necessary to keep your line "in hand," as it were,-not tight, but well out of the water, and ready for a short, sharp strike at any moment. The "whish" made by the 
line through the water is a token of bad striking, as is the pulling of the line completely out.

If the fish be missed, the bait should travel on as if nothing particular had happened; the clumsy fish that has missed his mark is well entitled to another turn, or perhaps some greedy companion may snatch the envied morsel from him.

Roach spawn towards the end of May, later than the gudgeon. They are in season from July to January, perhaps later, but it is cold work fishing for them in November, which is the best month. $\mathrm{Up}$ to October the gentle is the most taking bait : two or three should be put on the hook together, and frequently changed, for when dead and flabby they cease to be attractive. In default of gentles, which are not always obtainable, bread-paste, kneaded up with wool to make it tenacious, is perhaps the best bait. A piece about as big as a pea should be stuck on to the hook by a single movement; it does not do to manipulate it after it is once fixed. For winter-fishing a small red worm is the most enticing lure, and when the Thames is flooded, great quantities are taken with this bait by the fishermen, who then, poor fellows! are exercising their craft on their own account.

The worst of roach-fishing is, that the roach himself, when taken, is utterly useless, except 
as bait for the pike (of which hereafter). We have tried him in all ways - fried, boiled, broiled, water-souched-each successive mode worse than the last. We never tasted it, but we conceive that, like Cæsar and Pómpey, paper-pulp flavoured with mud, and roach must be very much alike -especially roach; but, like "P. P.'s" phlebotomy, he may do for "the poor." *

The general weight of the roach taken in the Thames is from two ounces to a pound; but we have heard of them as large as three pounds. The biggest I ever took was a little over a pound and $a$ half. The roach is on the whole a game fish, and capable of considerable resistance to any proposal for transporting him from his native element. The extraordinary fineness of the tackle used renders this, in the case of a large fish, a work of some difficulty; and we do not hesitate to say that a really good roach-angler is capable of any other species of fishing, and if opportunity offered, would excel in it.

The generic (scientific) name of the roach is "Cyprinus rutilus." It spawns, as stated, early in the summer, and, like most of the family, is very prolific. The fins are red (hence "rutilus"); and

* "But to bleed adventured I not, except the poor."-SwifT, "Adventures of P. $P$., Clerk of this Parish." 
this colour furnishes the readiest means of distinguishing it from its cousin the dace, hereafter to be described, whose fins are white, or nearly so.

We have mentioned "gentles" as the usual and best bait for roach. These may be bought at any tackle-shop, or from any fisherman; but it may be well to remark, that gentles are not all alike. There are gentles and gentles. Not ex quovis cadavere are the maggots on which the roach delighteth to feed taken. "The sun," "kissing carrion," may breed "maggots in a dead dog," but the roach turns up his nose at them. Gentles are born in bullock's liver, and when nearly full-grown cradled in bran, which scours and sweetens them. Sam, an intelligent young man who acts as my fisherman, tells me they taste "sweetish:"-I have never tried them.

\section{THE DACE.}

The dace ("Cyprinus leuciscus") is not only a near relation, but a companion and associate, of the roach. Their habits and food are the same, and it is very rarely that a good roach-swim does not afford dace, and vice versâ. We think, but we are not sure, that the dace affects a somewhat higher level in the water than the roach: the gud- 
geon feeds on the bottom, the roach a little above, and the dace somewhat higher than the roach. The same bait and the same tackle are used for both; but the dace is the more greedy or the less shy fish of the two, bites more freely, and is taken with larger hooks and coarser lines than the roach will look at.

The dace does not run nearly so large as the roach : a fish of a quarter of a pound may be considered a good specimen. It is more lively on the hook, and, in proportion to its size, shows greater sport, trusting more to the powers of its fins and tail than the roach does; the latter being apt to take an unfair advantage of its clumsy figure, and turning broadside to the opposing stream, cheat the guileless angler with the show of dimensions which it by no means possesses.

The form of the dace is rather elegant than otherwise. Its fins, which are white instead of red, the colour of the roach's, at once distinguish it from that fish; and its scales, which are small and closely packed, are exceeded in brilliancy by no river-fish (hence the appellation "leuciscus") except the bleak, and are used in making imitation-pearls and other very beautiful ornaments.

As an article of food-for man we mean-the dace is beneath contempt; but as a bait for a 
better fish, hereafter to be described, to wit, the jack, it is unequalled. The greedy tyrant of the waters is in some respects an epicure, and besides that the appearance of the dace in the water is very attractive, the fish itself seems to have an especial charm for its devourer. The form, too, of the dace is admirably adapted for fixing on to the flight of hooks used for spinning. A slight "wobble" is all very well in pike-fishing, but a roach is all wobble.

We have separated the dace from the roach, and placed him nearly at the end of his class, because with him commences the practice of the great art of fly-fishing. The gudgeon supplies the accidence of bottom-fishing, the dace of fly-fishing. In the spring and summer months the dace is altogether a surface-feeder; and with reasonably fine tackle, a midge, a blue dun, or a red ant, great execution may be done on the gravelly shallows without much strain on the skill of the fisherman. In the autumn he affects the same diet as his cousin the roach.

\section{THE BARBEL.}

Like a small minority of the intelligent youth of the present day, this fish is principally distinguished by its beard, from which it derives its 
name, and which consists of a pair of wattles pendant from either jaw. The precise mode in which these appendages are utilised by the fish in seeking out or providing food is not clear, but that in some manner they assist in the search, if not in the capture, there can be no question.

The barbel is the very hog of fishes; it feeds at the bottom, "routling" like a pig with its long snout among the stones, rotten weeds, and debris at the bottom of the stream. It is omnivorous, feeding largely on water-weed as well as worms, insects, fish, and garbage. That it feeds on the first we assert from the unanimous testimony of Thames fishermen; on the fourth, from the fact of our having frequently taken the fish while spinning for jack; and that it feeds on the last we assume from the fact of greaves being an excellent bait for it. Worms, however, are the ordinary bait used, and you often take barbel while fishing for roach with gentles.

Although voracious when on the feed, and by no means particular either as to the nature or quality of its food; no other fish which we are acquainted with is so capricious as the barbel. When they are in a taking mood, the well of the punt may be filled with them in a few hours; but one may fish for days or weeks without feeling a 
"tug." The capture also depends, in some inscrutable manner, on the locality. There are barbel holes swarming with fish, which may be seen at all times chasing one another about, turning on their broad backs, and performing all sorts of clumsy antics in the cool depths they rejoice in, but which are never known to take a bait. They are like the Laird of Macfarlane's geese, which are recorded to have "liked their play better than their meat." There is a barbel-hole near the mill-tail by Caversham Lock of this unproductive nature. We will venture to say there is a ton weight of fish within a very moderate space, but after long and fruitless endeavours, the attempt to catch them has been given up as hopeless by all the fishermen in that neighbourhood.

The mode of fishing is peculiar. The barbelpitch must be baited for several days or nights previously with quarts of great dew-worms embedded in clay. The fish collect in great numbers to feed upon the dainty morsels, and having grown bold from impunity, fall, occasionally at least, victims to the angler, who offers them just the same thing, with the slight addition of a barbed hook attached to a slender line within each. A hundredweight and upwards may thus be captured in a morning; but the line is often used in vain, the 
fish is not in the mood for taking, and three times out of four the worms expended, or assumed to be expended, by the fisherman, are thrown away.

The orthodox mode of angling for barbel is with a reel and line, both of considerable length, and the latter of moderate thickness, ending with eight or ten feet of gut, the last eighteen inches passed through a bullet, which is kept from slipping down by a No. 4 shot, playing the bait (the most taking is a large well-scoured lob-worm) just clear of, but almost on, the bottom. Ten or twelve yards of line are let off the reel, coiled at the bottom of the punt, and, aided by the weight of the bullet, are thrown out down the stream to the full extent of the length. The bait having reached the bottom, any slack there may be is at once taken up, and the line being moderately taut and passed under or round the fisher's finger so as to give immediate notice of a bite, the point of the rod but a few inches above the water, he waits with what patience he may for the desired result. This, as we have said, is sometimes long a-coming, sometimes it never comes, but when it does the fact is signified by a smartish jerk on the line. To this first summons, you, like an over-worked waiter in a second-class inn, pay no attention, but should your customer persevere, and ring the bell a second 
time, which he will do somewhat impatiently, you may strike, but not too hard; hard striking is always objectionable, and the barbel represents a heavy mass of matter, which is very apt to operate as a break upon tackle, when force is too roughly applied. When struck, your fish is absolutely safe, barring breakage; for your hook would be as likely to lose its hold on a piece of india-rubber as on this essentially leather-mouthed fish, and it is just a matter of discretion or taste what time you may spend in landing him. His piggishness is never more manifest than when he is hooked; he neither jumps out of the water nor runs out the line, but spreading his broad fins, putting his head well down, and opposing his great body to the weight of the water, he pulls in an obstinate, swinish way, never yielding an inch, but succumbing at last to main force-an ignoble prize, for the barbel is coarse to look upon and worthless to eat.

Another and a better mode of barbel-fishing is one more generally practised on the Trent than on the Thames. A longer, lighter rod than that used as already described is fitted with a "pirn," a kind of wooden reel, which runs round on the slightest possible pressure, without check of any kind, and which requires some little skill and experience to manage properly. This is furnished with some 
eighty or a hundred yards of "Nottingham line," a float eight or ten inches long, of trifling bulk, and a light lead of just sufficient weight to keep the bait at the bottom without stopping the float, which is then allowed to travel down the stream, dragging the bait with it, to any distance within the reach of the line which the nature of the bottom will allow. This is by far the most scientific, the most sportsman-like, and the most killing mode of angling for the barbel, and I commend it to the attention of my readers.

In the days of my youth, barbel were more confiding or more greedy than at the present time. Ignorant and unskilled as I was, and provided with the most ordinary tackle, I never failed to kill five or six fish in Shepperton Deeps, under the auspices of Purday ( $\mathrm{I}$ think his Christian name was John), the father or grandfather of the Purdays who still practise the craft in the same locality. Although of late years I have generally spent the autumn months on the banks of the Thames, and have frequently fished for barbel, I have had but one really successful day. The Court journalist was pleased to notify my success to the world; and if the record of that excellent paper be true-and I have no reason to doubt it, though I did not myself weigh the fish-I killed 
twenty-five fish, weighing eighty-four pounds, and but for the intrusion of a stranger, who coolly stationed himself at the tail of my swim, and whose fisherman caught a good many fish which he hauled out, I should, no doubt, have killed many more.

The barbel is known as the largest of the family of Cyprinide ("Cyprinus barbus"), sometimes attaining the weight of twelve or fourteen pounds. It spawns early in the summer. As an article of food it is utterly worthless, at least to man. Pike appreciate it when young, and its shape, like that of the dace, peculiarly adapts it for a spinning bait. I recommend its being used as such whenever taken. I cannot doubt but that this fish operates beneficially in the humble capacity of scavenger in the localities he affects. His large size, voracious and indiscriminate appetite, and habit of feeding at the bottom, justify the assumption. Mr Frank Buckland should take him under his especial protection.

\section{THE CHUB.}

The last of the "Cyprinide" to which I shall refer (for though both the tench and the carp 
may be found in the Thames, they are of comparatively rare occurrence, and not commonly objects of the angler's pursuit) is the chub, a fish for which, albeit he, like the majority of his congeners, is bad for food, and not good for sport, I have a latent affection. Although not properly a surface-feeding fish, like the trout or grayling, the chub seems really to go out of his way to afford the best sport in his power to the young fly-fisher who may have graduated with the dace on the shallows; and although a hungry, not to say greedy fish, to take him with the artificial fly is by no means an easy matter. The skill required to hook one large chub would suffice for a dozen trout or salmon. Of course, the youth and hobbledehoys are green, inexperienced, and easily captured; but to kill an old chub from two to five pounds weight with the fly-(I have never met with one above the latter weight) - is a credit even to the experienced fisherman. It is only during the late spring and summer months, or the early autumn, that the chub will take what is by courtesy called a "fly" on the Thames. This is generally an imitation of a humble bee or a great hairy caterpillar. At such times of the year, the chub occupies a station close under the bank, beneath an over-hanging willow, and immediately behind a 
substantial mass of weeds, into which, as a place of refuge, he is prepared to retire upon the smallest provocation. There is not a shyer or more easily-startled fish; it is therefore essential to throw a very long line, and to throw it deftly over the weeds and under the bough and short of the bank. To do this properly is not the work of the tiro, and the fisherman who brings home a good basket of fine chub is capable of far greater things in the art of angling. However long the line thrown, the approach of the fish towards its destined prey is plainly visible in the clear and comparatively shallow water it frequents, and it requires no inconsiderable amount of self-restraint to avoid the fly-fisher's besetting sin-striking too quickly. Strike, however, you must, and that sharply, so as to fix the barb into the by no means unaccommodating palate or lip of the fish. Unless this is done, the chub is nearly certain to escape, for, lying as it generally does, close to the bank, it could not run from you if it wished, which it does not, for its refuge and hope of safety are in the bed of weeds between it and you. The most dangerous manœuvre a fish can adopt is therefore of necessity put in practice: it rushes towards, not away from you, and a slack line is inevitably the result. Of course, the opposition tactics are to 
throw the point of the rod well back, and wind up your line as rapidly as possibly ; once get "a pull" upon him and the result is certain, and far too easy for sport; the fish, however large, comes heavily, stolidly to your hand, and the landing-net secures him. What to do with him, is the next question, and one which I confess I am unable to answer. I generally give him to a semi-civilised bargee, or an ambitious bank-fisher, who takes him home, and, I fear, gets the unmerited credit with his wife and family of having himself captured the "delicate monster."

A poaching but very killing way of taking this fish is to fasten a cockchafer, a humble bee, a hairy caterpillar, or, better than any, a large grasshopper, to a naked hook, and creeping under cover of the willows to the brink of the stream, yourself entirely concealed, pass the rod with a short line twisted round it, through the leafy screen, and unwinding the line, drop the bait on to the surface of the water as though it had been accidentally detached from the tree. This being exactly what the fish was looking for, he chuckles at his own prescience, and swallows the coveted insect with an audible smack of his lips, and a considerable appreciation of his own knowledge of the ways of the world. With a short line and a secure hold 
there is no possibility of your losing your prey; except by breakage of tackle, and that is an accident of rare occurrence, thanks to the general excellence of London makers.

In the autumn the chub takes the worm readily, but except in the mode first described, it is not in my opinion a fish at all worth fishing for.

The chub is known in the north as the "skelly," perhaps on account of the large size of its scales. Its scientific name is "Cyprinus cephalus." The epithet (Greek for a head) refers to its head being rather disproportionately large, particularly about the jaws-(we talk of a chubby-cheeked boy or a chubby-headed fellow). Like most of the tribe, the chub spawns during the spring months, about May: the fins are a dusky red or brown colour.

\section{THE PERCH.}

The Thames, as has been said, is occupied almost exclusively by fish of the order Cyprinida, just as Argyleshire is by Campbells, and Wales by the once-regal family of Jones; but a few other tribes are represented by isolated families. Such is the case with the Percida, a type of which, "Perca fuviatilis, is one of the commonest and 
most appreciated, for food, if not for sport, of the denizens of the river.

This fish is too well known to require description; a clumsily-shaped, awkward fish, but handsomely marked, and, when in good condition, by no means unpleasant to look upon, though essentially so to handle, the strong sharp spines on the dorsal fin inflicting a painful and not easily-cured wound. The hungry pike, although, when no more accommodating food is at hand, he will swallow the smaller ones, shrinks instinctively from any interference with adult members of the family; and this immunity from the attacks of other fish tends greatly to the increase in the numbers of the perch. Some of the Cumberland and Westmoreland lakes are stocked with them to the absolute exclusion of any others, and so quarrelesome and greedy are they, that the only wonder is that they have not, like the Kilkenny cats, annihilated themselves.

It frequently happens while fishing for gudgeon, that those confiding little fish suddenly, and without apparent cause, leave off biting. If you shorten your line a few inches, remove the red worm, and replace it by a minnow, the hook carefully passed through the upper lip, you will probably catch the responsible cause in the shape of an intrusive perch; and though he afford little sport, for a more faint- 
hearted fish does not exist, there are few if any in the Thames that can compare with him for eating. The smaller perch should be water-souched, or, if for breakfast, fried. The larger ones, say from half a pound upwards, are never better than when boiled, and, with the addition of a little plain sauce of melted butter and anchovy, afford a dish for an epicure.

The ordinary mode of fishing for perch is with a light rod, a long line, and a large float. Fine fishing is thrown away, for the perch is a greedy fish, rushes incontinently at the bait, and if given time enough is pretty certain to hook himself, though, as in the case of other fish, it is necessary to strike by way of clinching the bargain.

$\mathrm{He}$ is, as has been intimated, fond of gudgeon, although the feeling is not reciprocated; but his "favourite vanity" is the minnow, and great havoc the perch must make among that long-suffering race. I have taken six or eight out of the stomach of a perch of half a pound weight. The mode of baiting is very simple. Pass the hook (No. 7) through the upper lip, a good-sized shot having been previously attached to the line a few inches above; regulate the float-a large one-to a depth varying from four to six feet, and if in a stream, allow the line to run out, as in barbel-fishing, as far 
as you please. If there be no current, throw it cleverly, so as not to disengage the bait, to a considerable distance from your punt. The perch is a free biter, and no great amount of the assumed one thing needful to a fisherman-patience-is requisite. If you do not get a run soon, shift the place of the bait; that failing, shift yourself, and seek another pitch: In summer the perch, in common with pike and most other fish, affects the weed, and you cannot do better than fish in the immediate neighbourhood of a heavy mass impinging upon deep water. In autumn and winter they seek deep holes, and great numbers, sometimes twenty or thirty, may be taken from one such place. You must, however, be careful not to let many escape, for, once pricked, the perch becomes very restless, and is apt to lead or drive the shoal away.

This is not a treatise on Natural History, or I might comment upon a singular fact which has forced itself on my observation. I have hardly, if ever, opened a fish that did not prove to be a female, and, at whatever time of the year, always with spawn fully developed, yet the spawning-time of perch is in April or May. I have twice referred to this curious fact in "Land and Water," with a request for information on the subject, but without effect. 
My attention was first drawn to it by Sam Scott, a clever young Thames fisherman, who fishes for his livelihood at Laleham, and whose means of observation are naturally very extensive.

The weight of perch varies from a few ounces up to three or four pounds. I once saw three killed of the latter weight, or very near it, in one day; but although larger-sized ones are occasionally recorded, I have never seen one.

\section{THE EEL.}

We may assume that no one angles for eels; still, as the eel is an inhabitant of the Thames, we will not ignore its existence; and for culinary purposes it perhaps enjoys more consideration than many of the more sought for denizens of that stream. Eels are of three kinds : the snigwhich, coated with sand, occupies the costermonger's shallow basket, and is so accustomed to be skinned alive as to have acquired a proverbial indifference to the process - the flat-nosed eel, and the round-nosed eel. Their ordinary food consists of worms, fish alive or dead, and animal matter of all kinds, whatever its state and condition.

A most effective mode of taking them is, to 
enclose in a large-meshed net some carrion enveloped in straw or hay, and attach it by a rope to the bank. A considerable number will be captured by pulling the mass suddenly to land after it has lain a week in the water. Another mode, more in the retail line, is to thread a quantity of worms on worsted, tie them together in a lump, and dropping the slimy ball from a stiff rod into the deep water, pull it suddenly up; after sufficient time has been given for the eel to gorge two or three, he will find himself landed before he can make up his mind to part with the mouthful.

The most legitimate mode of fishing for eels is, however, by night-lines or bank-runners; and we would suggest that for this purpose a single hook is better than a double, a worm a better bait than a fish, and four or five loosely-twisted strands of strong hemp or lightly-twisted line better than the strongest gimp. The power the eel possesses of breaking anything of the latter description is simply marvellous, and a single line he will assuredly bite through; but the loose strands get between his teeth. The line must be sufficiently long, but care must be taken that it will not reach to a rock, a post, or even a large bank of weeds, or the eel will avail himself of the purchase, and break your line though he die for it. 
A most exciting sport is eel-spearing, though the spear is plunged blindly into the deep mud. We practised this art long years ago in the fen ditches in Huntingdonshire, and with considerable success. Terrible hard work that eel-spearing is, and the man who can stick to it for a couple of hours may aspire to six shillings a day as a navvy! In the lakes of Westmeath the process is more scientific, at least requires more skill. On a sunny day the boat floats over the shallows of the lake, and the great eels are detected through the bright clear water, half in, half out of their holes, sitting on the threshold of their houses, as it were, enjoying the fine weather. Spearing them under such circumstances is very like spearing a trout or salmon as practised in the olden time, a sport in which we have joined, though we suppose we ought to be ashamed to own it.

Eels run down to sea in the autumn, for the purpose of depositing their spawn, and are then in their best condition. When they return does not appear quite clear; but the fry, the "eel-fair," as it is called, proceed up the rivers in May, meeting the smolts who are then descending. That eminent naturalist Mr Buckland has stated, in a recent article in "Land and Water," that the smolts devour the young eels; but I do not think they are open 
to the imputation, neither has any testimony been produced in support of it. The smolts in salmon rivers go down in myriads, the eel-fry ascend in equal numbers. Nothing stops them, no obstacle stays their course, they wriggle over the damp stones, they cross the dewy meadows, they climb the perpendicular sluice-gates, they ascend every ditch and streamlet, they occupy every water, running or stagnant, and afford food not only to man, but to numberless birds, beasts, and fishes.

I know that it has been doubted, but I take it as a recognised fact, that under no circumstances do eels ever breed in fresh water. A given number of eels turned into a pond having no outlet whatever, may, and probably will, decrease in number; they will never increase. It is well known that they occasionally quit the water at night, and wander over the dewy grass in search of food or suitable dwelling-places; and the instinct by which they find their way to the water is as marvellous and inexplicable as are all the operations of instinct when judged by the light of reason. In Ireland and Scotland eels abound, but are held in a sort of superstitious horror by the natives. A Highlander would as soon eat a snake as an eel, and can hardly be persuaded to touch one for the purpose of extracting the hook. The Irish Celt spits at the 
mention of its name, as he does when he talks of a toad or a lizard, or other object of St Patrick's anathema. There are, however, eel-fisheries in some Irish rivers-Ballyshannon, for instance,which are highly productive; and I have often wondered that one has not been set up in Tweed, which swarms with the brightest, whitest, and largest eels I have ever seen. They are, moreover, terrible enemies to the Salmonida.

The reader will please to bear in mind that the eel is a fish, and has scales and fins, as a fish ought to have. It is classed by Yarrell as "Anguilla" with the distinction "acuti-" or "lati-rostris" according to the shape of its nose. According to this author, they are capable of a considerable amount of domestication, at any rate of taming. They will come to call, eat out of your hand, and distinguish their feeder. Eels, however, can hardly be considered as eligible pets, and would, I think, be quite incapable of anything like disinterested friendship.

The eel is a great sleeper, and spends all the winter in its muddy bed, from whence it is sometimes rudely extracted by the eel-spear abovementioned. 


\section{THE PIKE.}

In these days of broad-cloth and "financing," it seems strange that this truculent, greedy tyrant of the fresh waters should have been selected (perhaps, however, merely in "canting heraldry") for the cognisance, and adopted under its various synonyms as a surname, for many old families of good repute. The "Peakes" still flourish in Derbyshire; the Geddes, once a warlike race, are still numerous in the Lothians; the Broughams bear the "three white luces," and they, we know, were "an ancient coat" in the days of Shakespeare. In the old time, however, might made right, and the rough of mood and ready of hand ruled the vassals of the land.

"Little reck'd they of a tame liege lord."

And the attributes of the pike-courage, strength, and swiftness-were arrogated to themselves by the noble and the chivalrous.

No fish is more common, or more hardy, than the pike. He inhabits alike stagnant pools, ponds, lakes, and streams comparatively rapid, like the Avon or the Trent. The still waters, however, are essentially his habitat; and though frequently found at the tail of a rapid, he affects 
quieter parts of running streams, and thrives best in great lakes, where food is plentiful and readily procurable. Except that he eschews vegetable matter, and prefers fish to any other kind of food, the pike is simply omnivorous. Fish, flesh, fowl, are alike to him; the young of his own species, the dace, the gudgeon, the roach, a young duck, a moor-hen, a gaping frog, a bunch of garbage-all are seized with equal avidity when he is in the humour to feed; and, to do him justice, it is very rarely that he is not in the humour. A gentleman, who has no wish to communicate his name to the Society for the Prevention of Cruelty to Animals, once threw thirty young sparrows and starlings, one after another, to a large pike in a lake, and he seized and swallowed the last with the same avidity as the first.

No one wishes $\mathrm{Mr}$ Buckland success, in his praiseworthy attempt to make the Thames a salmon river, more fervently than myself; but so long as pike exist there in the numbers they doand they will continue to exist in those numbers so long as the Thames flows down to the sea-it is simply waste of that pearl of fishes to introduce it to the water for the mere purpose of being swallowed by "Esox Lucius," as it inevitably is within a week of its leaving the breeding-ponds. 
When salmon were found in the Thames (they were never abundant, for the Thames is not naturally a salmon-river), pike, a fish of comparatively modern introduction, were unknown. Even should one smolt in ten thousand find its way to the sea and return a grilse, which, so far as I know, has never yet happened, there are pike in the Thames that would swallow him like a gudgeon. I have seen a jack, of three pound weight, which had taken a trimmer bait, seized by his grandfather, or some other elderly relative, and have had a great fight before, to our mutual disappointment, the elder was compelled to loose his hold. Last year, in the Thames, I caught a barbel of nearly six pounds weight that had evidently been seized and severely bitten by a pike; and there are wellauthenticated instances of great fish being taken from the water, choked in their effort to swallow a moor-hen or a full-grown duck. One instance of the latter in Norfolk, and another in Rutland, have come within my own knowledge.*

There are several ways of fishing for the pike; and as it undoubtedly affords the very best and

* In Mr F. Buckland's museum there is a cast of two pike, about five pounds each in weight, the one choked in his attempt to swallow the other. There is no appreciable difference in their size, yet the one is half-way down the throat of the other. 
most exciting sport within their scope to those who do not throw a fly for trout, and have not the luxury of salmon-fishing, I shall describe those several ways; and though, individually, I may hold one kind in higher estimation than another, I am well aware that great skill, perseverance, and knowledge of the art, are required in making a successful practitioner in any.

\section{TRIMMERING.}

Trimmers and night-lines may, in the opinion of many of my readers, come within the category of poaching implements, and I confess they somewhat savour of irregular proclivities in a sportsman; still a fish is sometimes wanted for dinner; time is sometimes wanting for regular fishing; jack must sometimes be taken by proxy; and some young sportsmen are, happily or unhappily, ready to take the sport the fates provide them, and be thankful-

"Turning to mirth all things on earth,"

as only the young in heart can. In a great lake or a large mere well stocked with pike, no better or more productive sport can be desired than that of trimmering. I have killed a hundredweight and upwards of jack in a day. 
The best mode of setting night-lines is by what are called bank-runners. I do not mean a peg with a slit in it, and a coil of line at foot, though many good fish are so taken; but one made with a round piece of wood like a cotton reel in its upper part, and a long strong spike to fasten it on to the bank, or, a safer mode, into the bed of the river, a foot below the surface. The reel is passed through a circular iron nail, round which it runs freely; twenty yards at least of good water-line must be attached, with a leaden bullet tied some two feet from the end, to which a single hook on six or eight inches of gimp, strong, but not over-thick, is fastened by a slip knot. There are various modes of baiting, and various baits are used-gudgeon, dace, roach, or frogs. Agreeing probably with dace, roach, and frogs, I prefer the first, and, indeed, have placed them in order of precedence according to my own judgment. Some fishermen, with a baiting-needle, pass the gimp down the side of the bait under the scales, or under the skin of the frog, "handling him tenderly," as old Izaak has it, so that the poor creatures may keep alive for many hours. This is, without doubt, a most killing method, but unnecessarily cruel, for a jack will take a dead bait, or at least one which he believes to be in a dying or helpless state, almost, if not 
quite, as freely as a live one, or a bait so cleverly spun as to have the appearance of vigorous life.

To bait with a dead fish, it is merely necessary to pass the gimp by means of a baiting-needle right through it from the mouth to the fork of the tail : there is no need of tying. The bullet, which lies at the bottom when the line has been thrown in a few yards from the shore, will give the play, the lighter bait floating above it in the most captivating manner, and, if not too heavy, offering no appreciable resistance to the removal of the supposed victim to the lair of the savage ogre, who conveys it thither to be devoured. I think that, unless very ravenous, a pike never bolts his fish at the moment of capture. He seizes him by the head or across the body, holds him hard and fast, and retires to his resting-place among the weeds to swallow him in private. Night-lines should always be laid in the neighbourhood of weeds.

Except dead fish, however, the pike eschews dead animals as food. He may be taken by what is called a fly, which he no doubt mistakes for a young duck, or moor-hen, or a water-rat; but in such case the strike must, as we shall hereafter explain, be instantaneous. No sooner is the sham bait taken into the mouth, than it is ejected with a force, common to all fish, but to me perfectly 
incomprehensible, and the nature of which I would gladly learn. I have known a dead bait, though firmly fastened, driven upwards from the hook at least eighteen inches along the line. The pike will, as I have said, swallow a dead fish, but I think nothing else dead. When Scott's affrighted Sacristan listened to the ominous song of the water-kelpie,-

"A blue swollen corpse is a dainty meal,

And I'll have my share with the pike and the eel,"-

he might have taken comfort from a knowledge of this fact; as Cuvier may when he told the devil, who threatened to eat him, that "it was all bosh, his horns and hoofs showing him to be graminivorous." Marryat, too, libelled the fish in "Jacob Faithful." "I shouldn't wonder," said old Jacob, when he heard a splash in the water, "if that wasn't Bill." Sure enough it was Bill; and when recovered a week afterwards, he was so disfigured "by the pike and the eels, that he was 'no good to nobody.'" This, I say, is a libel on the pike; the ravenous brute will eat almost anything, but it must have at least a semblance of life.

To return to our trimmer. This engine is too well known to need description. I would merely suggest, that in extensive waters it is necessary to lay them well to windward, and advisable to stick 
a feather (black, as most visible) on the red or lower side, which, when taken by a fish will become the upper, and afford a mark more readily caught by the eye than the peg.

The mode of baiting is, to pass a single hook (a good-sized salmon-hook is about the best) through the skin just under the back-fin. The fish sustains little injury, and, if strong and healthy, may be released at the end of four or five hours, with freedom in lieu of "a good-service pension," and very little the worse (in our opinion-his might be less unbiassed) for the discipline he has undergone. Of course, having in the first instance taken the bounty, in the shape of a gentle, a fly, or a red worm, he ought to have been prepared for the chances of war.

The best bait for a trimmer in English lakes is the roach, as being, for his sins, the strongest and most tenacious of life; in Scotch, the parr-not the young salmon, but the barred-trout-"Salmo salmulus"-so classed, and properly classed, by Yarrell, the greatest of authorities on fish, and recognised as such by every observant sportsman whom I have ever met, though contradicted by inexperienced persons who talk or write of what they know not. A young salmon, however carefully put on the hook, dies in a very short time. 
Poor little one! soft and unused to hardships, it speedily succumbs, and is useless as a lure; but a parr, an adult gudgeon, or a roach, will tow a trimmer about for hours without material damage, and if its praiseworthy attempts to catch a flat are unsuccessful, may, as suggested, be released by the grateful and humane fisherman, with the conviction that its span of life will be by no means shortened (it may have been made to seem long enough) by the ordeal it has undergone. It is great sport hunting a trimmer which has been taken by a big fish. A pair of strong oars will scarcely catch the bobbing, diving, disappearing cork; and, when caught, it requires delicate handling to hold and properly play the struggling fish. There is no aid from the yielding, elastic top-joint of a rod, but the exact strain that line and hook will sustain without breakage must be carefully calculated ; and I have known a run to last pretty nearly as long, and, while it lasted, to afford nearly as much excitement, as a fox-chase. On the whole, trimmering, under proper restrictions, and in suitable waters, is by no means bad sport.

\section{TROLLING.}

I have already quoted the learned judge's dictum, "Some port is better than other, but there is no bad 
port." Many modes of fishing are better than trolling, but trolling is not a bad mode; and as it is a very killing mode, I shall venture to describe it.

The implements necessary for a troller are a baiting-needle, a piece of brown thread, a pair of scissors, and a dead-gorge hook. The latter, like almost everything else, to be good, should be moderate in all its parts-of moderate weight, moderate length, the hooks moderately curved, first inwardly, and secondly, more slightly, in an outward direction; a swivel is not essential, but very advantageous. The rod, about fourteen feet in length, must be stout and stiff; in fact, if not too heavy, the stouter and stiffer the better. The rings should be fixed, and can hardly be too large, the great object being, as will be shown hereafter, to allow the line to run out, without check or hindrance.

Almost any fish of proper size will answer as a bait, but perhaps a large gudgeon is the best that can be used: it is tough, well shaped for the purpose, and its flavour much appreciated by the greedy jack. The mode of baiting is, after killing the fish, to draw the shank of the hook, by aid of the baiting-needle, clean through it, entering at the mouth, and bringing it out at the fork of the tail. A few twists of the thread below the gills and 
behind the tail fasten it securely. Your scissors are then brought into play; the fins are cut close off, and the tail neatly cropped, so as to afford no catching point for the weeds in which you are to fish. It is true that a fish thus manipulated bears no greater resemblance to its original self than a swathed pappoose to a sprawling baby; but the pike is probably guided at least as much by smell as by sight, and it is intended to drop this delicate morsel immediately under his worship's nose. He looks upon the lure as a maimed and helpless victim, and at once takes advantage of its assumed condition.

Many Thames fishermen troll throughout the season, but the practice is more general in the early part, from July to October, before the weeds have rotted down sufficiently to render spinning practicable. Standing at the head of the punt, you throw your bait with an easy spring to a moderate distance, right or left, dropping it under the bank, beneath roots, or in any casual opening in the weeds which will admit of its passage. Long casts are not necessary, but an adept will toss the bait to an inch where he intends it to drop, and the leaded weight carries it at once to the bottom where the great sulky pike,

"Hush'd in grim repose, expects its evening prey." 
It is possible that the indignation roused by the sudden intrusion of a despised small fish, evidently in bad circumstances, into his domestic privacy, may have something to do with the result; for the pike is not very keen at this time of the year, and rarely leaves his lurking-place in search of food, taking, like the spider, whatever good luck may send him. Be that as it may, the temptation is irresistible, at least unresisted, and a slight curl in the water, a scarcely visible wave in the weeds, with an almost imperceptible check on the line, tell you that your bait is taken. Later in the year-say in October-when the pike comes out to feed, this is followed by a sharp run of a few feet or yards, as the case may be, towards his lair; to which, with the fish crossways in his mouth, as a dog carries a bone, he invariably returns before swallowing it. In the early part of the season, however, but a few inches of line are taken, sometimes none, and the fisherman is in pleasing doubt whether he has hold of a jack, a root, or a weed. Whichever it be, his tactics are of the simplest order-a masterly inaction. Letting out two or three yards of line, in case they should be wanted, you have nothing to do but look at your watch, note the time exactly, and then smoke the pipe of expectation; read your 
"Land and Water," or a chapter of some book on field or forest, or, better still, a page in the great book of Nature, passim. Do you see that waterrat?-water-vole is his proper designation-the sole representative of the ancient race of beavers in Great Britain. He is running along the water's edge, stopping at intervals to wash his whiskers and gaze fearlessly into your face. $\mathrm{He}$ is an interesting beast to watch, and, when fairly scanned, not so ugly as his long yellow teeth and angular visage might make you fancy; there is an air of benevolence, too, in the water-rat's face, when you examine it closely, which is expressive of his character, and quite unlike that of his distant cousin "mus rattus," the land rat. Guiltless, or all but guiltless, of animal, food, the water-rat feeds almost exclusivelyon vegetablesubstances. He may nibble a dead fish if he find one, but has neither the will nor the power to injure a live one; therefore harm him not, but watch him as he moves towards you like a clockwork animal, his short legs hidden under his thick body, never diverging from his track, but swimming across the water as he meets it in exactly the same plane-so buoyant is his body-as that in which he runs.-But you look at your watch, and at the movement your cool visitor turns up his inelegant little tail and dives down 
out of sight, reappearing at the mouth of one of his numerous holes on the distant bank.-Ten minutes have elapsed, and now you strike pretty sharply, and the wretched jack, who has swallowed without compunction what he considered a helpless fish, his appointed prey, finds the barbed hook inextricably fixed in his vitals or in the lower part of his throat. Under such circumstances the pluckiest of fish could not be expected to show sport. The pike is never very plucky, and on a dead-gorge hook shows very little pluck indeed. On the whole, many, I think most modes of fishing are preferable to trolling.

\section{LIVE-BAIT FISHING.}

Predaceous birds and beasts affect certain localities with surprising constancy. There are jungles in India, and, thank goodness! coverts in England, that always hold a tiger or a fox respectively, whatever the number of either that may have been killed out of them. Shoot a pair of falcons or of owls, if you can find it in your heart to do so, and in a very short time a fresh pair will assuredly take their places on the same cliff or in the same hollow tree.

The same rule holds good, if possible, more invariably, with respect to fish. Whether salmon, 
trout, or pike be the object of your pursuit, there are certain traditional holes or lairs that will never fail you. An old Scotch keeper, on taking affectionate leave of me the night before I returned southward, said, solemnly, "A' may be deed before ye come back, but there's ae thing I'd warn ye-in yonder hole, where the swirl comes round the mickle stane, there's aye a trout beastie, an' a grand ane!" I never verified his words, but I am quite sure John McIntyre spoke the truth, and kill as many as you will from that particular spot, there shall never lack others to take their place. As with British soldiers in a breach-one man down, another steps gallantly into his place-so it is with trout and pike. I know an especial run in Penton Hook, a noted place for live-bait-fishing, out of which I have taken two, three, or four in a day, and out of which, within the space of a few yards, I verily believe that hundreds are taken in the course of every year.

You may use your trolling-rod for live-bait-fishing, with the reel and line thereunto appertaining ; a large, fat float, as big as a dumpling, must be provided, through which some three feet of the line are to be drawn; and firmly fastened with a peg. The hook, which is of course tied on gimp, consists of a single eel-hook with a triple-hook 
floating free four inches below it. The single hook is passed either through the lip of the bait or under the back-fin. As in trimmering, a small bullet counteracts the bait's propensity to swim on the surface of the water.

Standing at the head of the punt, which for the time is stationary, your boatman hanging on to the rushes, or the willow, or the bank, you drop your bait quietly a few feet in advance, or laterally according to the current, and work the line in such a manner that the float, though pulled in a different direction, shall drag the bait willy-nilly into all sorts of odd corners and casual openings in the weeds near which the pike may be supposed to lurk.

A large roach is your best bait, and if there be a pike within a reasonable distance of your swim, he is almost certain to take. His presence is intimated by the violent agitation and partial immersion of the float caused by the poor roach's vain efforts to escape his enemy. Another moment, and your bait is seized, and the float disappears beneath the surface, travelling rapidly towards the pike's headquarters. Strike, but not too quickly nor too hard; your fish is almost certainly hooked, and if of large size, will show capital sport.

I am aware that many fishermen look upon this 
mode of fishing as poaching; but though akin to it, I cannot admit it to be so, though it may be neither very artistic nor very exciting. Pike are such ravenous, gluttonous brutes, that all sentimentality is out of place with regard to them; and they are so prolific, and the larger ones so wary, that no possible harm can accrue from any mode of rod-fishing however destructive. Besides, the hooks are not large, and are not bolted like a deadgorge; a fish has a fair chance of making a good fight for his life, and he generally makes it. Livebait-fishing should always be carried on in the immediate vicinity of weeds : in the open water, spinning will of course be practised, between which and trolling live-bait-fishing may be considered as intermediate.

\section{SPINNING.}

Spinning is certainly the most scientific, the most. artistic, and, on the whole, the most killing mode of fishing for pike ; it may also be fairly called the most sportsman-like. Trimmering depends little upon personal skill or experience; live-bait-fishing is but little above it; and trolling-though I am loath to say anything in dispraise of it, seeing that it is an art thought worthy of culture by a large proportion of Thames fishermen-strikes me as 
rather akin to shooting pheasants running or hares sitting.

Spinning takes a high class in the noble school of fishers; and the man who excels in it may fairly rank himself as the equal of any other professor of the art.

The best bait for spinning is a dace; the fish is sufficiently tough, and admirably shaped for the purpose. The roach is too broad in proportion to its length to spin properly, and the scales of the gudgeon are not sufficiently bright to attract the notice of the pike. I think, too, that this fish has an especial affection for the dace. On one occasion last year, I was fishing in company with a gentleman who was certainly not my superior, either in practical or theoretical knowledge of the art. He was provided with dace, I had only roach to fish with; he caught nine fish to my one, and when he kindly gave me a couple of dace, I killed two pike with them. No doubt a dace spins much more truly than a roach, but I do not consider that the result was much affected by this fact; for, as I shall state hereafter, a "wobble" in the bait is rather advantageous than otherwise; but I believe that the pike, being well fed and dainty, felt and manifested a decided predilection for the one fish over the other. 
I would not trespass on the ground taken by one of the best practical fishermen of the day, $\mathrm{Mr}$ Cholmondeley Pennell, or attempt to add anything to the instructions given in his admirable work on the pike, by laying down rules either for baiting the hook or using it when baited. My readers cannot do better than consult his pages; but I may say, that the S hook invented by himself is the simplest and best form of spinningtackle that can be used. With it I captured the thirty-pound fish recorded below. In fixing the bait, the great point is the tail, which must form a slightly obtuse angle to the line of the body; and the body should, by a careful adjustment of the liphook, be made as stiff and straight as possible; this shape is more readily obtained by the use of Pennell's hook. You will require at least forty yards of line, plaited, not spun, and thoroughly prepared to prevent kinking ; your rod, of fourteen or fifteen feet, should be sufficiently pliable, not so much so as a fly-rod, but of far greater strength, and something between it and a trolling-rod. The bait is thrown out with a sort of jerk, requiring very little exertion, but when made by skilful hands astonishing the beholder by the distance to which the bait is thrown. Many Thames fishermen will, without apparent effort, shoot out twenty-five or 
thirty yards of line; but distant throwing is not all that is required. To spin well, you must throw to exactly the spot you intend. A punctual man is not one who gets to his train ten minutes before it starts, neither is a good spinner one who throws ten yards beyond the mark; he must know to a foot where he intends his bait to drop, and if he mean to throw twenty-five yards of line, he must neither cast twenty-four nor twenty-six.

There are many accomplished fishermen who, in anticipation of a kink or stoppage in the running of the line, will twist it round their little finger and thumb, and allow it to run off in the most artistic manner. This is the poetry of the art, and I commend its exercise to those who would excel in it, but I confess it is beyond my powers; and as a rule, you will do well enough with a well-prepared line, if you coil it as you draw it in, foot by foot, at your feet.

Fish down-stream ; keep your punt within a few yards of the weedy side, the head at an acute angle from it; make your cast across, and well in advance; work the bait towards you, so as to cover the whole stream, and finish by a few strokes from the top of the rod in the space between the head of the punt and the bank of rushes or weeds alongside. If a fish strike, return the blow as 
quickly as possible ("bis dat," \&c.) I know this is controverted, but, so far as my experience goes, I have never, while spinning, lost a jack by striking too quickly. When he is struck, hold him hard, and play him cannily.

If in good condition, well baked, with a pudding inside, and very simple sauce, the pike will satisfy you that your labour has not been thrown away.

I hardly know whether I shall appear to be presuming on my readers' patience, but I cannot resist the temptation to give an account of the capture of a very large pike I was fortunate enough to catch last autumn.

One does not go to Scotland for pike-fishing. The fisherman who travels northward is supposed to be in search of higher game; and there are many lakes in Scotland abounding with pike which are rarely or never fished for them, the angler being generally ignorant of their existence. In fact, the introduction of pike to Scottish waters is of comparatively recent date. Fifty years ago there was not one in Loch Awe; they were put in by some evil-disposed or officious " person or persons," and have since increased, as their nature is, beyond all reason, to the manifest diminution of the trout, perhaps of the salmon. Every reedy bay or shallow inlet is now stocked with this ravenous 
fish; and Kilchurn Bay, near Dalmally, at the head of the lake, perhaps affords as good pike-fishing as is to be found in the United Kingdom.

I wonder have any of my readers ever visited Dalmally? If not, let them shape their course thither the first opportunity that a dull season or a long vacation offers. There is no scenery in Scotland, or, to my thinking, out of it, that surpasses-there is very little that approaches -that of the Western Highlands. Its beauty is only equalled by its variety; moss, moor, and mountain alternate with rich "pastures and fertile corn-fields; the streams and rivers tumble down the most precipitous courses, presenting a succession of broken water and cascades endless in their variety, and falling at last into lakes stretching to an extent correspondent with the grandeur of the scenery, and studded plentifully with wooded islands. Loch Awe is twenty-four miles in length. Ben Cruachan, the monarch of the mountains which reflect themselves in her bright waters, rises well nigh four thousand feet, and some of the mountains that are his companions are of little inferior height.

At Dalmally, nestled among woods and rocks, stands one of the most comfortable, unpretending hotels to be met with in the North country, and I 
have found very many most comfortable and most reasonable hostelries in that much-abused land. I have no faith in the accounts of those bilious, grumbling tourists, who, year by year, indite their prosy complaints of ill-usage and extortion for the benefit of the readers of the Times in "the silly season," when alone they have a chance of a column. No one is more impatient of imposition than myself; but my motto is, "live and let live ;" and if tourists would take to their hearts the fact that a Scotch innkeeper has a short twelve weeks out of the year during which he must earn his livelihood, and get the means of paying rent, rates, and taxes, they would hardly complain of being charged Is. $9 \mathrm{~d}$. or $2 \mathrm{~s}$. for their breakfast, and 3s. $6 \mathrm{~d}$. for their dinner, charges I have seen held up to execration in the public prints, and which I declare I have been almost ashamed to pay, when I considered their inadequacy as compared with the awful amount of the liberal and often expensive viands provided for the vigorous appetite gained in the keen Scotch air. However, to return to the inn at Dalmally. After fishing in Tweed for salmon, I arrived there one afternoon late in October last. I found the lake, like the river which ran into it, in high flood; indeed, it had been raining almost incessantly for six weeks, and, 
judging from appearances, was likely to continue for six weeks more. A slight change in the temperature, which capped the loftier peaks with snow, added greatly to the beauty of the scenery, but by no means lowered the lake, the waters of which spread over miles of meadow lying around it, and almost laved the walls of the picturesque old castle of Kilchurn. A lake, however, will fish more or less at all times and under all circumstances, so I determined to spin for a pike. My fisherman, one Malcolm, a civil, sturdy Highlander, with a strong predilection for whisky, very keen and well skilled in his craft, led me, by a sloppy walk of two miles, to the mouth of the "Orchy," the largest of the rivers which empty themselves into Loch Awe. Here we found a useful sort of boat securely fastened by chain and padlock to a projecting alder. Malcolm produced the key, and loosing the boat, after baling her out, for she was half-full of water, we rowed for a mile or more down-stream, and "commenced" fishing under the walls of the old castle, but for some hours with little success. Bad as the weather was, there was evidently worse coming. The wind blew in gusts and squalls, driving the mist and foam before it over the troubled waters of the lake; the wild ducks skimmed along close to the surface; the gulls and 
rooks flitted and drifted high above it; and the sensitive fishes, as usual, lay sulking and fasting in the depths below. I had hooked and returned, very much to Malcolm's disgust, two or three handsome but undersized fish, and killed one of three or four pounds, when he proposed that we should run out some distance into the lake, round a point of the island on which the castle stands. It was a hard pull, for our course lay into the very eye of the wind. The waves by this time ran very high, and the boat pitched and tossed as she might have done off the North Foreland. At last we reached our ground, and making a long cast from the boat's head as she topped a wave, I struck and hooked a heavy fish. For a minute or more I imagined it was off, and had left my hook stuck in a rock, so solid, heavy, and motionless was the strain on the line. At the end of that time, however, my doubts were removed by the fish stirring, and to some purpose, -running out at least forty yards of line, and then stopping abruptly, as though to consider what was next to be done under existing circumstances. With some difficulty, Malcolm kept the boat's head to the wind, and rowed towards the place where, in very deep water, my intended victim lay, doggedly motionless. The strain on the tackle was considerable, for the rod was not, like a salmon-rod, 
springy to the butt, but comparatively stiff, as spinning-rods must be; and I was forced to humour "Esox Lucius" a good deal, as the boat danced up and down. "He's twenty pound, Malcolm, if he's an ounce!" "Hoo! hoo! there's nae fish here the noo more than fifteen or maybe saxteen pun, and few eneuch of them. It 's a big beast though, deil doot it." At length I came nearly over the fish, and tried to lift it a bit. I might as easily have lifted the rock behind which it lay. But in a second or two it took the matter entirely into its own hands (as I might say in the West of Ireland), running up the lake, at a slower pace certainly, but with greater strength, and for a greater distance, than any salmon I had ever hooked. I began to think that the hundred and twenty yards of line which the author of a recently-published fishing-book talks of so glibly, as commonly run out by a salmon, might be the fact in the case of a pike. However, after clearing my reel of some sixty or seventy yards, I felt I had a pull on the fish, and winding up my line as quickly as possible, I brought it under the point of the rod, and eventually raised it to the surface. Such a monster I had never before beheld! A salmon of thirty pounds is a grand fish, but there is nothing terrible in his appearance, as there really was in that of 
my monster pike. As the head appeared above the wave, the beast made a rush, the shoulders and part of the back well above water, the savage mouth wide open, and for fifteen or twenty yards dashed along with a force which, if resisted, would have broken a rope, making the water boil again, lashing it, seemingly more in rage than despair, with its powerful tail. Happily my gear worked well, and dropping the point of the rod, and easing the line a bit, I let it run as far as it would, and then brought it cannily back again. Three times, each with diminished force, did the deluded beast try with mad rushes to break the good tackle, and then, grimly succumbing, floated helpless on its side. Fortunately, I had brought a gaff with me, and Malcolm, by its aid, speedily transferred my capture to the boat. It was a splendid fish, in capital condition, and weighed fully thirty pounds, the largest pike that has ever come under my personal notice as killed by rod and line. I forwarded it at once to Mr Frank Buckland, who most kindly "cast" it for me. The cast was painted by the eminent artist $\mathrm{Mr} \mathrm{H}$. L. Rolfe, and having been "set up" in a case by Edon, of Chichester Terrace, Kilburn Park, the best fish-stuffer of my acquaintance, forms a most interesting object in my house. It is, independently of the great size of the object, 
really a work of high art, and could not possibly be distinguished, lying in a bed of dried rushes, from a real fish. The skin was afterwards stuffed by the same taxidermist, and is now honoured by a place in Mr Buckland's museum at South Kensington. The skin was, however, much shrunk by the heat of the plaster, and a very inadequate notion of the original dimensions can be obtained from the stuffed specimen. Mr Buckland, in his notice of the fish in "Land and Water," says : "The pike arrived by the limited mail in perfect condition. She is one of the handsomest fish I ever saw. The tiger-like, dark chocolate markings are beautifully seen. She is full of roe, the total weight of which is twenty-one ounces. By weighing a series of separate grains, and averaging the result, I find the total number of eggs in this one fish is $292,320 . "$

FLY-FISHING.

Fly-fishing for pike sounds somehow like a contradiction in terms. Flies for jack seem something like Mr Bumble's cheese for the sick pauper, or the economical Lady Bountiful's Soyer-soup at three farthings a quart. We have, however, taken jack-under a pound weight, certainly, but still jack-both with the May-fly and the March brown. 
We need hardly say that in both cases we were fishing for trout, but the fish took the fly and was taken.

We have, however, little doubt that the so-called fly used in fishing for pike is taken by that voracious monster for a newly-hatched moor-hen, dabchick, or duck, for which he has a decided predilection, clearing off, one by one, a whole brood of the twittering, unconscious, helpless victims. No doubt the increase of water-fowl is greatly kept in check by the ravages of the pike. No sooner is a brood launched upon the waves of life, and of their native element, than, by some telegraphic means of which we are ignorant, the fact seems to be communicated to the biggest jack in the neighbourhood, who immediately commences " decimating " them after an Irish fashion, that is, by eating nine out of ten of the downy morsels.

Fly-fishing, as it is styled, for jack, is, however, a very artistic and sportsman-like mode of capturing him. There is much skill required in playing the lure, and the fish, with a single moderate-sized hook slightly struck into his hard jaw, shows more sport, and enjoys a better chance of escape, than under any other circumstances. The method is very little understood or practised ; indeed, except in stews and still lakes, where the fis's is abundant 
and the bait scarce, it would be ineffective. I therefore give it by no means the prominence it would otherwise deserve. The original inventor, if I may so style it, of the system, was I think Lord Gage, who has practised it successfully for upwards of thirty years in the large pieces of artificial water in his park at Firle, near Lewes, out of which water I have myself taken with the fly fish of fifteen pounds weight. Perhaps the most successful fisher in this line is Mr Hayes of Hertingfordbury, near Hatfield, who kills from eighty to one hundred fish a year. His flies, if flies they can be called, are composed almost exclusively. of the gray feathers taken from beneath the mallard's wing. A thin silver twist is wound round the body to attract the attention of the fish, and the head is indifferently black, red, or blue. In addition to the large salmon-hook generally employed, a smaller one is tied under the feathers on the same plane, but on the opposite side, and is doubtless very effective. So far from dressing the fly in a fashion to make it swim truly, a great desideratum in salmon-flies, Mr Hayes makes a slight bend in the tail to cause a "wobble" when it is drawn through the water, so as to resemble as nearly as possible the action of a newly-born aquatic bird. The rod required for this sport is 
the same as that used for salmon-fishing, but rather more than ordinarily stiff. Fine gimp must be attached in lieu of the gut casting-line, or the fish will nip it in twain with his sharp teeth, as a sempstress bites her thread.

The pike is classed by Yarrell as the chief of the family of "Esocide," which numbers among its members the flying-fish. It is the "Esox Lucius" of Linnæus, the "pickerill" of ancient writers. The family is tolerably old, being noticed by various writers as early as the reign of Richard II. When in condition, the pike may be considered a handsome fish; and being bold and fearless of close examination, is liked in ornamental waters; but there is something savage and unpleasing in its aspect. The single dorsal fin is placed very far back, near the tail, and is of large size and immense power. To their united action is due the wonderful rapidity with which the fish moves through the water when in pursuit of its prey or escaping from danger. 


\section{II. \\ đTined.}

\section{THE TROUT.}

I CONFESS to approaching the subject of troutfishing- "trouting," as it is generally called in the North-with considerable diffidence. So much has been written on the subject, and so well written, that it seems a work of supererogation to add to the quantity; but a fishing-book containing no chapter upon trout-fishing would be "Hamlet" with the part of Hamlet left out; and I therefore, as in previous chapters, offer to the young angler the results of my own experience and observation for just what they may be worth.

When I commenced writing the present volume, I determined not to "read up," to consult no authorities, and to record no experiences except my own; this on no principle of vanity, or supposing that I could learn nothing, but from a 
desire of avoiding repetition of truisms, or the promulgation of erroneous dogmas vouched for by recognised authorities. I have observed, in all books of Natural History, the great mischief which arises from the system of "reading up." Naturalists are not infallible, however scientific, accurate, and observant they may generally be; and if one in good repute make a mistake-and I never read a book on the subject without detecting manyevery subsequent writer adopts, and so perpetuates it.

The only two books on the subject of fishing that have come under my notice for many years are Walton's "Complete Angler" and Stewart's "Practical Angler." From the former I am free to confess I have derived neither pleasure nor profit. There is no doubt but that in his day the worthy citizen was an excellent angler; he was also a simple-minded, kindly, prosy, and very. vain old gentlewoman; but he lived in days when coaches travelled at the rate of five miles an hour, and Izaak Walton must even then have been considered a very slow coach indeed. I would not whisper it at the "Walton's Head" or the "Walton's Arms," or hint it at the "Jolly Anglers" or the "Rest," or any other resort of his so-called disciples, but to my readers I will impart my 
private conviction that there is now at least little practically to be learnt from Izaak Walton's "Complete Angler," and that the reading of it is rather heavy work than otherwise.

Mr Stewart's admirable little book is of a different stamp. I am convinced that a more skilful angler than Mr Stewart does not exist. He has probably killed a hundred trout where I have killed one, and in a day's fishing would give me a start till lunch-time and then beat me. With this firm conviction, I shall still venture to recommend to my readers an entirely opposite mode of fishing to that so ably advocated by that gentleman.

Before discussing the subject, I will record-only to show the extreme divergence of opinion that existed, and probably still exists, among writers on the subject of angling - a few random notes which I accidentally stumbled upon in an old memorandum-book, and which I had extracted from various authors some thirty years ago, when I first became a follower of the "gentle art." Here they are :-

"Rods. - A rod cannot be too stiff; it is impossible to throw a line lightly, or at all against the wind, with a pliable rod."

"Purchase your rod in Ireland; they are always pliable, 
and play from the butt : no fisherman will condescend to use a stiff rod."

"Flies. - The colour of your fly must be adapted to that of the water-a dark fly for dark water, a bright fly for bright water."

"It is useless fishing in dark water with a dark fly."

"The brighter the water, the darker the fly, and vice versâ."

"In trout-fishing three or four flies should be used."

"No fly-fisher requires more than one or two flies on his cast."

"Reels.-A multiplying reel is indispensable in fly-fishing."

"A multiplying reel is a mockery and a snare; it is sure to fail you at the pinch."

I cordially assent to this last dogma; but I have merely selected the above, from some dozens more or less contradictory, to show how widely really practical men differ in their opinions on the most essential points, and to justify my offering advice founded exclusively on the results of my own experience and practice.

With regard to rods, I very much prefer a light, rather long, pliable one,-one that plays nearly down to the grasp,-an Irish rod, in short; and my favourite maker is Kelly of Dublin. No doubt a rod of this description is bad to throw against wind; but I hate throwing against wind, and I never do so if I can possibly help it; the necessity is of rarest occurrence. $\mathrm{Mr}$ Stewart, the great 
advocate for stiff rods, urges that the strike is so much more quickly made than with a springy one. I have never experienced any failure from want of rapidity in striking, and when a fish is struck, though you cannot haul him out of water by the hair of his head, as it were, you are very much less likely to lose him; and the sport shown by a fish hooked with a springy rod is far greater than when a stiff one is used. To fish up-stream is Mr Stewart's grand specific for sport; and in sluggish streams, with the wind blowing up, no doubt it is the true way to fill your basket, and should, where practicable, be adopted. I once found myself fishing in a Hampshire stream of this description. The water was not only sluggish but very dirty. I had one side only, and three gentlemen were fishing the other. They fished down-stream and killed three fish; I fished up-stream and killed ten.

Most trout streams, however, run rapidly; and it is to me more of a toil than a pleasure to keep perpetually whipping, while your flies are returned almost instantaneously, and, unless you are very expert, occasionally in a state of entanglement. In worm-fishing, no doubt the up-stream fashion is very much the most killing; and as you fish with but one hook and a short line, the objections I have referred to do not apply; but I hate-(I won't 
say despise ; for no one has a right to despise a mode adopted and much esteemed by others)-I hate worm-fishing for trout. There is something refined and poetical about trouting which is hardly in unison with an impaled worm. The play shown by a fish thus hooked is very inferior, as the bait is generally swallowed, and your pull is from the gullet at best, instead of the hard palate or bony, unsensitive lip. All fishermen who fish for their livelihood, and not for sport, adopt this killing, and, to my mind, less sportsman-like method. However, there are times of drought and flood, and times of the year when the fly is worthless as a lure, and there are streams so small in their dimensions as to preclude its use. In such cases, the worms may be fairly used. Scour them thoroughly. This is best done in clean, dampish moss, changed daily for four or five days, always pressing it tightly, and placing the worms at the top. They will squeeze themselves through to the bottom of the vessel, and in so doing, get rid of the earthly aliment always present in them when freshly dug. Use a No. 8 hook, and unless the water is very fine, tolerably strong tackle. A single shot, three or four inches above the hook, will sink it and cause the bait to play. Your rod is short and stiff. Walk $u p$ the stream, and throw 
a very short line a few feet before you, allowing the bait to fall back with the stream into every little hole or eddy caused by a sudden turn or a submerged stone. When conscious of a bite, allow a short time to elapse before striking; and though you may not have much sport, you will catch plenty of fish.

The best months for trouting with the fly are April and May, or, in some waters, May and June.* When the May-fly goes down, about the middle or end of June, the trout are fat, shy, and lazy. They come on to the feed again in the autumn, and, though the fish then taken are undoubtedly smaller, as heavy a basket may be made in the Northern streams with the fly in September, as in any month of the year.

The best days for trout-fishing are cloudy, breezy, and warm, the water slightly coloured from recent rains, but not swollen ; and if, having these advantages, the glass is rising, and really there are trout in the water, it is your own fault if you do not catch them.

Fishing-tackle makers and fishing-books, which are generally written in their interest, provide a change of flies for every month in the year, and

* Worm-fishing begins in July, and may be advantageously carried on to the end of the season. 
almost for every day in the month; but the best trouters I have ever known carry but few varieties in their books, and are generally chary of changing their cast, even though the fish decline taking as readily as might be wished. Of course, I do not mean that one fly, like one Irishman, is as good as another,- "or better;" but I think that, with one or two exceptions, where nature can be closely imitated,-the March brown, the red ant, the stone fly, the gray and green drake, the black and brown palmers, for instance,- - size and colour have more to do with the question of taking than anything else has. There are some flies which fish in certain rivers affect, but which are almost useless elsewhere. I have never killed trout in any Southern stream with the little "white-tip," so famous on Tweed, and I believe that neither the "governor" nor the "coachman" are of much avail out of the Southern and Midland Counties. My object is not, however, to go into detail on this or any other branch of my subject. I advise my readers to provide good store of the flies I have named as standard flies, and trust to local experience and the advice of friends in filling up the spaces of their book as occasion arises.

In fishing for trout, it is essential to keep as far from the bank as you reasonably can, and never to 
allow your shadow to fall on the water. Shadows terrify fish even more than they did the Third Richard on the eve of battle; and though fishes are supposed-I think proved-to be incapable of hearing, in the ordinary sense, I am convinced that the quieter you are, the better your chances. Although unfurnished with ears, fish are singularly sensitive, and may be perfectly conscious of the vibration of the air caused by sound, though not striking on a tympanum.

The wind being to your back, or on your quarter, commence-(fishermen, I know not why, always use the term "commence" for "begin")-commence fishing at the head of the pool or rapid; throw a short line at first, and cover the ground nearest to you, gradually lengthening your throw as you proceed, but never letting out more line than you can perfectly well manage. If loose in the water, you cannot strike rapidly; and though a fish may hastily mistake a sham for a real fly, he speedily finds out the mistake, and before you can get the line taut, as it ought to have been at first, has spit it out contemptuously three feet from him. The fall of the fly on the water is the most killing moment, and you must, therefore, be careful that the fly touches the water first. A yard or two of line flopping in the water is apt to 
scare the fish, and take off his attention from the falling fly, though he may not connect the two together in his own mind. Under the bank is generally the most likely lie for a trout; but there is no absolute necessity for him to choose the opposite one.* If the further bank be beyond reach, content yourself with fishing under the one on which you stand, which you may do cleverly by throwing a little short of the centre of the stream, and working the cast round. A tremulous motion imparted to the stretcher as it falls on the water is decidedly captivating; but the killing movement is that which, without dragging, impels the fly along the water in a more or less gliding fashion, stopping at intervals as water-insects do. The stretcher, by the way, is the end fly, and generally the largest, the more readily to retain its precedence ; the others are called "droppers," and when two or more are used, should be fastened by a small loop to the casting line, five and three, or eight, six, and three feet from the stretcher. If your cast be composed of flies of the same size, fix the most likely one as a stretcher-the chances are three to one in favour of its first attracting the

* An angler, especially a young one, is apt to be bitten ripae ulterioris amore, and in straining after the distant shadow, neglect the proximate substance. 
notice of the fish, and first impressions are, as every one knows, all important.

In trouting from the bank, under ordinary circumstances, a landing-net is not necessary-the largest fish may be coaxed on to a shelving bank without difficulty, and if a lift be necessary, use your hands, not the line. When wading, it is different; unless you are prepared to lead every fish to the bank, which in broad streams is a sad waste of time, a landing-net is indispensable. A belt round the waist will be found very convenient to stick the handle through, and if kept well behind, will not be in the way.

Spinning the minnow is a deadly mode of capturing trout, especially large trout. In the Thames it is almost the only recognised method of fishing, and many gentlemen-among whom we may mention Mr Gould, the naturalist, Mr Sachs, and $\mathrm{Mr}$ Lukyn-have attained marvellous skill in the art of throwing and working the lure. A goodsized minnow is without doubt the most effective bait; but there are various imitations, such as Ogden's "kill-devil" and "phantom" minnow, which are almost as effective, and much less troublesome. Whether a real or sham bait be used, the great object is to make it spin truly; the wobble, apparently so seductive in the case of the pike, has the 
very opposite effect with the trout : your bait must spin as evenly and truly as the worm of a screw. A long cast is frequently necessary, and great skill in the management of the bait when it falls in the water is essential to insure success. A fish once hooked, however, ought never to escape. Your hooks are strong and numerous, your tackle, though not coarse, capable of bearing any reasonable strain; and a Thames trout, though a strong fish, and sometimes weighing from eight to twelve pounds, does not display anything like the generalship of a salmon when fighting for his life. A few trout have lately been taken with the fly in the Thames, but the prevalence of the pike must ever, in spite of the praiseworthy efforts of $\mathrm{Mr}$ Buckland and $\mathrm{Mr}$ Ponder, prevent the Thames from becoming a good trout river.

In the Tweed, the Esk, the Dee, or in any broad wading river in Scotland or Wales, where good trout abound, the fisherman should not only be provided with his bait-kettle, duly immersed in some cool, sequestered spot, but also with a small can attached to the strap by which his landingnet is suspended, such can containing six or eight live minnows with which to rebait when necessary. Trout will no doubt take a stale bait, a salted bait, 
or a sham bait, but they have a decided predilection for a fresh one.

The trout, I need not say, is of the noble family of "Salmo," and is distinguished as "Salmo fario." Wide differences will be observed both in size, shape, and colour in specimens taken from different streams, lakes, and rivers. The weight varies from a few ounces to ten or twelve pounds; and while some streams afford fish of handsome shape and bright colours, others are inhabited by lanky, dusky specimens, pale-fleshed and almost worthless to eat. I consider that the great cause of these differences is the food. Where that is plentiful the fish grow and thrive; where it is not, or there are too many mouths to partake of it, they are, as a natural result, lean and ill-favoured. No doubt, however, there are many distinct species of trout which have never yet been classed by the ichthyologists.

\section{THE GRAYLING.}

The grayling ("Salmo thymallus") is essentially a monkish fish; at least it is said to have been introduced by the monks, who

"Made gude kail

On Fridays when they fasted."

And the legend is corroborated by the alleged fact 
of the fish being found in no streams but those on the banks of which old monasteries stood.

I must remark that I do not recollect having myself met with grayling in Thames, or even Tweed.

The term "thymallus" is derived from a supposed smell of thyme emitted by the fish when first taken out of the water. I confess that, though I have smelt with the nose of faith, I have never been able to detect it.

"When cats is out," Sam Weller tells us, "fruit is in." When trout are out of season and cease to rise at the fly, grayling are in season and afford most excellent sport. The mode of fishing is precisely the same as that adapted for trout, but the flies should if possible be smaller and finer, and the strike more instantaneous on the rise-in fact, it is impossible to strike too quickly. In deep clear water the fish may be seen rising almost from the bottom, and the moment you see him you must strike, and when you strike you do so with a tolerable certainty of hooking your fish. The enormous back fin enables the grayling to rise with a rapidity no other fish can: it shoots upwards, seizes the fly, and descends in less time than the motion of your hand can follow: the dive of the dabchick, which disappears at the flash of the gun, is the only thing in nature which, within my ex- 
perience, equals the grayling's quickness; strike therefore, as I have said, at the rise. The grayling comes into season in September, and may be fished for throughout the winter months. The best streams are the Derbyshire Wye and Derwent, but it has been introduced into many others. As a rule, it avoids the swift streams, and when introduced into such is generally found to descend gradually lower and lower, until it finally disappears.

\section{WHITE TROUT.}

Whether the white trout- "Salmo trutta" of Linnæus and of Yarrell-be, as some naturalists affirm, identical with the bull or gray trout- "Salmo eriox"-it is not my purpose in this place to inquire. I think not; I think that the fish are entirely different, and that there are a great many distinct species of trout which have not yet been classed or described. There is the "sewin," for instance, which may or may not be the grilse of the white trout. I cannot believe it to be so; if it were, why should it be confined to Welsh rivers only? There is the "parr"- "Salmo salmulus,"-which is so like the young salmon as to be considered identical with it, and which has very properly obtained legislative protection in virtue of the similarity. There is a 
little barred fish, abundant in the Western Irish lakes, which the natives call a "gub," the diminutive of "gubberhorn," a term which I believe means "little" in Erse, and is commonly applied to a tricksy, semi-malignant spirit recognised by the Irish peasant. These "gubs," which run from an ounce to a quarter of a pound, are in number numberless, and from their constantly rising at the fly constitute a serious hindrance to white trout fishing. They are yellow, well-shaped fish, with five or six well-defined dusky marks across the back and sides. I do not think that any naturalist has as yet classed or named them, but I trust they may find a place in the next work on the natural history of fishes.

To resume the subject of white trout, I am content to follow Yarrell, and to consider it a distinct fish, and fully entitled, by its various good qualities, to the precedence over other trout apparently expressed by the affix "trutta." Handsome in shape, harmonious in colour, delicious to eat, a free riser, and a sufficiently game fish, there is in my opinion none that excels, none that equals, the white trout in the qualities most desired in a fish; and I hold that a good day's white trout fishing in one of the western Irish lakes is about as enjoyable as anything that falls to man's lot in this weary world. 
I have said that the white trout is sufficiently game; by that, I mean that he gives most excellent sport, running out many yards of line, jumping out of the water three or four times in succession, to such a height as to bring your heart into your mouth, and try all your skill, dashing hither and thither, sometimes round the boat, sometimes under it, but never sulking, never attempting to cut the line or rub the hook out of its mouth, or take any other unfair advantage of the honest angler, but, when fairly beaten, admitting the fact, and coming into the net without useless resistance.

The best days for white trout fishing are rough, stormy ones,-the rougher and stormier indeed the better. I have been out when four strong men could with difficulty keep the boat's head to the wind, or prevent her drifting bodily on to a leeshore; but there is comparatively little art in killing fish in such weather, they are certain to hook themselves, and neither coarse tackle nor rough flies will materially prejudice your sport. When the sun shines bright, and the water is clear, and the weather calm, it is a different thing altogether; fine tackle and good throwing are absolutely essential ; and the longer the cast, the finer the tackle, and the softer the fall of the fly on the water, the better the result. 
I consider a limber, springy rod quite necessary; the wild jumps of the fish are rendered ineffectual by the give-and-take action of the elastic rod; and when, as is frequently the case, the fish rushes under the boat, you have only to let the point descend well into the water, and passing under the keel renew its position on the other side.

White trout fishing is generally practised with two rods in the boat, one at each end; the boat is rowed up-wind, and allowed to drift back over the favourite spots, "broadside on." Various flies are used on different lakes,-the size and colour depending upon the state of the water; but whatever the fly, it should never be without a piece of gold or silver twist round the body - the latter for choice. The mode of playing is to draw it rather rapidly towards the end of the boat from which you are fishing, but quite clear of it. It is scarcely possible to strike too quickly at a rise.

A fresh-run white trout, cooked within a few hours of its capture, is about as delicious a dish as can be set before an epicure. Those who purchase salmontrout from their fishmonger in London have very little notion of what the fish was when first taken.

The best white trout fishing in the United Kingdom-perhaps in the world-is to be found in the West of Ireland. It was there that, in direct 
opposition to the views of better and more experienced fishermen than myself, I established, to my own satisfaction at least, the principle of fine fishing for white trout. I had arrived at one of the most beautiful and most hospitable dwellings in that beautiful and hospitable country, one lovely morning in August. I had been travelling all night and all the preceding day, but there is nothing more refreshing after $a$ long journey than a day's fishing, especially if not of a fatiguing nature. Lake-fishing is always easy, at least to the principal parties concerned; though the boatmen in that stormy district often have a hard time of it. I have known four strong men, pulling with all their might, occupy two hours in getting to the head of a lake not two miles distant, and scarcely then attain their object. Such was not the case on the occasion I refer to. The surface of the lake was smooth as a mill-pond; the mountains, which formed a natural wall a thousand feet in height, against which the waters rested, and which, for aught I know, sustained them to an equal depth below, the red berries of the rowan, and the white fleeces of the sheep which fed, in some miraculous manner, along the almost perpendicular face of the rock, reflected as in a mirror.

Fishing was pronounced to be out of the question, 
a delusion, an absurdity, a mockery; but I had travelled six hundred miles to fish, and fish I would, though offered all sorts of apparently more feasible outlets for the destructive energy which Cobbett declares, not without truth, to be the distinctive mark of all English country gentlemen. "Come, let us go forth," says my host after breakfast, " and see which of God's creatures we can slay!" Rabbit-shooting, sea-fishing, seal-shooting, flapper-hunting, grouse-shooting, even goat-stalking (for there is a wild breed of goats which inhabit those mountains, active as chamois, and difficult to approach as red-deer), were in vain suggested and in turn rejected. In the end I had my way, and, like "the swans on sweet St Mary's lake," we floated double on the surface of ours, "boat and shadow." With a light, springy rod, a fine line, and a London-made bottom scarce thicker than a hair, I commenced fishing, and, to the surprise of my companions, shortly rose and hooked a good fish. There were better fishermen than myself in the boat, but their tackle was comparatively coarse, and I think that I am within the mark when I say that I caught two fish to their one. In the course of the day we killed full thirty white trout, and the merits of fine fishing have ever since been recognised in those pleasant quarters. 


\section{THE SALMON.}

"How you, who are so fond of hunting, can have patience for fishing!" is a remark that has frequently been made to me. "Fish? No! I have not patience for fishing," is a remark I have often heard. What, then! is patience, not the least among the cardinal virtues, sunk so low in modern estimation that its possession is rather deemed derogatory than otherwise? But patience alone, highly as we prize the virtue, will not make a fisherman, far less a fisher of salmon. Have you a quick eye, a light hand, a strong arm, a swift foot? above all, have you strong nerves and a cool head? Have you skill to throw a long, light line, and coolness to stand on a slippery rock to do it? Is your wind all right, and does your pulse beat true time? All these physical qualities will find ample scope in salmon-fishing, and without them do not hope to excel. I remember, years since,-

"When my limbs were strong and my courage was high,"-

going forth with my rod one close, hot day in September, to a favourite pool in the Owen Duff, in Ballycroy - at that time my own property from mouth to source-to throw a fly for the last time 
that season. It was because I was bound to leave the same evening that I went out; a more hopeless attempt was never made. The sun was bright, there was "no wind in the air," it was a breathless calm; the heavy rain of the previous night had swollen the river, and it was at the time coming down in a dark flood, level, and sometimes over the banks. However, as it was my last day, I was determined to throw a fly, though but for the pleasure of throwing it. Walking up to the Greensod Pool, I commenced operations. My fly was an Inch-y-quin of the largest size, as is fitting in heavy waters, and there are few, if any, more killing flies on the Western Irish waters. Kelly, of Dublin, ties it admirably, and old Mr Lees, of sporting and post-office celebrity, never fished with any other. "Commencing," as both Irish and Scotch fishermen term it, at the tail of the rapid which feeds the pool, I threw a long line well over. At the first cast there was a palpable break in the water. Could it be a fish? In such a state of things I could not believe it possible; it must have been a piece of floating bog-wood, or a mass of turf torn from the bank, and hurried down the boiling stream! Again I threw, and the fly floated with the stream a few feet above the spot where the break, if break it was, had been. There was 
no mistake this time, the dorsal fin and several inches of the back of a monstrous fish were plainly visible above the surface of the dark water. My heart was in my mouth, but I had recourse to the old formula, which ought to be present to every salmon-fisher's mind-one, he comes up! two, he goes down! three, I strike! I did so, perhaps more forcibly than was altogether safe or necessary: it is curious how little force, if properly applied, is required to fix the hook. I struck with effect; and in another second I was dashing along the rough, flooded, dangerous bank at the speed of a foxchase after my destined prey. No time for thought or pause-no chance of picking footsteps or choosing my course. The stream was running ten miles an hour, and the fish appeared to resign himself entirely to it; sometimes rolling over, sometimes sailing almost on the surface, sometimes diving to the depths below, he carried on directly towards the sea, from whence no doubt he had travelled that very morning; fortunately, my line at the first cast was not of any great length, and the fifty yards in reserve constituted a handicap in the unequal race; but every nerve was strained to the utmost to prevent a breakage, which would inevitably have occurred had I failed for a moment in wind or speed. A ditch, some 
fourteen feet wide, full to the brim, intersected my path. "Run round, Jemmy, and give me a help on the other side!" Jemmy did so, and in his excitement offered me, as I jumped, the sharp end of the gaff-the gaff itself, in fact, instead of the handle. I sprang over, and avoiding the proffered aid (?), was safely lugged up the oppoșite bank by my faithful but confused attendant. A terrible moment of suspense ensued. In the jump I had necessarily slackened the line; had the fish escaped?. For a moment my heart sank within me, but throwing the butt of the rod well forward and rapidly winding up the line, I found, to my intense joy; that the fish was still firmly hooked. We were now in Pwlgarrow, and for the first time I got a real pull at him. The broad, deep water apparently suggested a change of tactics; and after swimming for a few minutes up and down, the fish sought the depths below, and rested like a $\log$ at the bottom, with the weight of thirty feet of water upon him. Meanwhile, with my arms fully employed, and almost altogether held high above my head, I was exposed to the attacks of myriads of midges, and troops of horse-flies. The air, as I have said, was still, sultry, and oppressive; and surely the fox in the fable, or the carrier at Gadshill, was never better bitten or stung. I suffered 
terribly. The fish lay like a log, or rather a rock, at the bottom: how to move him was the point. I then tried for the first time what I believe to be the only available "tactic" under such circumstances. Lowering the point of my rod until it touched, nay entered the water, I kept up a long, strong, steady, continuous pull at the full tension which my tackle would bear, in a direction almost at a right angle with the line of the fish, as he lay with his head up-stream. The effect, though it was some time before it became apparent, was, no doubt, to cause him considerable difficulty in holding his position; gradually, and by slow degrees, he would attempt to ease the strain upon him, slightly turning his head in the direction of the pull. As in all temptations, the first downward step was a stride on the road to ruin. The large surface of his side exposed obliquely, in however small a degree, to the force of the stream, rendered the position untenable, and in half a minute more he was careering through Mr Lee's then new pool, and running his headlong race seaward. There is a gorge not far below, through which the water hurries at great speed, the bank on one side shelving abruptly down to the rocky edge. Here Jemmy, well knowing that the salmon would pass down the rapid at a comparatively slow pace, and, 
of necessity, close to the shore, had stationed himself in advance, the ready gaff, already plunged into the water, in his hand. As the fish passed, Jemmy, standing knee-deep in the stream, struck him well and fairly, and, half overpowered with his weight and the strength of the stream, struggled manfully ashore, landing him at my feet with a triumphant yell that might have graced the victor in a faction-fight. The salmon weighed full twenty pounds. I overheard Jemmy subsequently giving a detail of the exploit to a brother fisherman; his narrative was more poetic, but less accurate, than my own. "The weight was near thirty pounds. The master, more power to him ! had run two miles without stopping, barrin' the halt the skaming vagabond" (not meaning the master) "had made in Pwlgarrow; he'd surely have got to the say itself," but for the prodigious acumen and wonderful pluck of Jemmy himself; winding up with "and when his honour saw the baste lying there, and me atop of him, 'Jemmy, you blaggard,' he says, 'that's the foinest gaff that ever was made in or out of Ballycroy,' says he, 'and there's half-a-crown for ye!'" Whether the hint was taken matters not to my readers, and I must apologise for the egotistical character of this episode; but I was anxious to show that 
patience is not the only requisite in salmonfishing.

I have said that I greatly prefer a springy rod to a stiff one. This, I know, is contrary to the opinion of many good fishermen; and they say, with truth, that with a springy rod it is impossible to throw a long line against the wind. I answer, like the lodger who met his friend's objection that there wasn't room to swing a cat in his lodgings, by saying he didn't want to swing a cat. I seldom want to throw a long line, and never against the wind. You may sail pretty close to it with such rods as I use, made by Kelly of Dublin ; no better are made, and their pliability is of enormous advantage in such a race as I have just described, rushing madly along over stock and stone, sometimes jumping, sometimes scrambling, sometimes tumbling. It is impossible with a stiff rod to keep that steady, constant hold on the fish which maintains the grip of the hook on the mouth, but the springy yielding rod compensates, as it were, for all irregularities, by its accommodating elasticity, and I firmly believe, from its persistent, though no doubt weaker strain, kills the fish in less time. I hate the drivelling, tedious, delicate mode of handling a fish practised by many no doubt good fishermen. I read of men being four, five, or six hours killing 
their fish. Miss Lloyd was reported in "Land and Water" to have had one on for, I think, twelve hours, and it escaped after all. "The play is not worth the candle." I have been an hour, nay riore, before I killed my fish, but that has been under special circumstances. As a rule, little over a minute to the pound is sufficient, just as a penny a minute will, under ordinary circumstances, pay, if it do not satisfy, a cabman. I know I ought to kill more deliberately-secundum artem, as Molière's doctors would say, but I am content to kill absque morâ. The largest fish I ever captured, he whose antecedents are duly recorded in "The Autobiography of Salmo Salar" weighed thirty pounds, and was gaffed within little more than forty-five minutes from the time he was hooked. I killed several fish last season from eighteen to twenty pounds, and not one took more than twenty-five minutes to kill. A fish, from the time he is hooked, should never be allowed one second to breathe, far less to collect his ideas and mature his plans for escape. "Butt him, yer sowl!" howls Paddy; "Gie him the butt, mon!" shouts Sandy; "Stick to him, run with him, never let him rest," say I.

The art and mystery of fly-tying is a great art and a great mystery. You must "tie" something 
which has no "correlative" existence in the heavens above or in the earth beneath, or, which is most to the point, in the waters under the earth, and which, at the same time, must differ in no important requisite of motion, appearance, or colour from things which really have existence. A superstition long existed that salmon, during their sojourn in fresh water, lived like the last victim to incredulous science-the Welsh fasting-girl-without food. The fact that unscrupulous fishermen found a parr-tail, or half an eel, or a dollop of fat worms, a most killing bait, rather shook the theory; and although there are some still credulous enough to believe that their victim is seduced into toying with the exquisitely-painted morsel they have provided for him out of sheer admiration for the artistic merit displayed, just as there are some very young men who believe that the bouncing: school-girl he sits next to really keeps up her stamina on the tiny morsels she so daintily toys with at the dinner-table, the notion is now exploded. The salmon is in truth a most greedy feeder; his digestion, like his appetite, is very active, and, in common with birds and beasts of prey, when in difficulties, he ejects the food recently swallowed; hence the myth which no one takes the trouble to verify or disprove, that no 
food is ever found in the stomach of the recentlykilled fish. What a salmon conceives an artificial fly to be it is difficult to say,-probably some marine insect or embryo form he has been accustomed to in the recently-quitted sea, or which his instinct tells him he may expect to find in his new quarters. The latter hypothesis explains to my mind the superiority of one fly over another in different waters; there is no question but that local flies, even of the roughest manufacture, are far more effective than the most beautifully-tied specimens which are used with deadly results in other waters. Try, for instance, one of those gray or red, rough, wingless, palmer-like monstrosities (locally designated "grubs" and "scorpions") so deservedly popular on the Usk, try it on the Spey, or the Tweed, or in fact on almost any other river, and what will be the result? I venture to say you would never raise a fish; and I am bound to say that the best of my Tweed flies have been treated on the Usk with a contempt they hardly deserved. I doubt not that, were the insect inhabitants of the different rivers captured and compared, there would be found some striking points of resemblance between the artificial flies and the respective living creatures which they accidentally simulate. My readers may object that the gaudy 
feathers employed present a gorgeous spectacle quite unlike the sober colours of the creatures which inhabit the slimy depths of salt or fresh water; but they must remember that the confused mass soaked in the water is totally different from the bright hues with which, dry and finished, it comes from the tyer's hands; besides, except that of the jay, which is always used in the breast, and the golden pheasant, which generally somewhat protrudes, the brightest feathers are on the back of the fly, and, if it float properly, concealed from the vision of the fish. For myself, I cannot tie a fly-I tried formerly, and partially succeeded, but I can buy infinitely better ones at a very. moderate cost, and in general the fisherman on the water will, for a trifling consideration, especially if you are genial in manner and skilful in practice, supply you with far better flies than the most skilful amateur can produce, or money purchase. Still, I by no means decry the art; it is most useful, and to those whose time is sufficiently at their own command I strongly recommend the acquirement of it. The best way is to take lessons at one of the London or Dublin shops: the fee is, I believe, generally a guinea.

To my mind, a knowledge of the size and pervading hue of the fly is much more important than 
the pattern, the size must be regulated by that of the water, and the colour in a great degree by its colour. Fish object to startling incongruities; a small fly is useless in a heavy water, and in a light one a large fly only scares the fish ; small, bright flies are essential in small, bright water, and large flies, conspicuous with gold or silver twist, tell best in heavy, dark water.

The number of flies to be used depends upon circumstances, Mr Francis, in his comprehensive work upon angling, published two years ago, says, if I remember rightly, "two or three; " but except in his valuable work, I never heard the latter number suggested, or of their being used by any salmon-fisher. In rivers like the Tweed, the bank, on one side of which, at least, is shelving, and generally free from rocks, and in lakes clear of water-weed, two flies may sometimes be used with advantage; but I question whether the disadvantages do not preponderate. Two flies, no doubt, afford the opportunity of practically testing the questions what size and what predominant colour is for the time being most in accord with the fishes' capricious taste, and you have, as it were, a double chance; the extent of a fish's vision must begin and end somewhere, and one fly may be within while the other is beyond 
his ken. Two flies, again, are more likely to attract his attention than one. On the other hand, if there be a rock, or a weed, or a post, you are sure to be hung up on it, in which case you inevitably lose your fish. This you constantly do at the last moment by the disengaged fly catching in the landing-net, a weed, a twig, or the bank itself, up which the fish is actually being raised. Again, it not unfrequently happens that while you are most artistically playing your fish on the stretcher, your fish all unconsciously is as artistically, and with equal effect, playing the dropper-the result, the hooking of a second fish of equal or larger size, the two immediately commencing a wild round dance, diversified with occasional antatgonistic tugs, and ending with breakage of tackle and the escape of both. There is, however, sometimes an advantage in fishing with two flies, which, though it must come under the category of a "fluke," may fairly be placed to the credit side, as may flukes in skittles, croquet, or billiards. Without, therefore, condemning the use of two flies, or altogether ignoring their advantages on some occasions, I advocate and practice the fishing with only one.

A fish foul-hooked, if small, affords capital sport. I assume that most of my readers know that a fish is foul-hooked when, by some chance, the barb 
has struck on the side, or the tail, or the fin. If small, I say, a fish thus hooked shows capital sport, but a large one has the odds too much in his favour; you may find in such case that you have caught a tartar, one you cannot take with you, one that will not let you go-it is like riding a pulling horse in a halter; not only does the fish experience no sense of pain (a fish's pain under ordinary circumstances is probably but slight), but you have no command over his movements. Steering apparatus, to be effective, must act either at stem or stern, but here your rudder is like one fixed amidships, and operates as the weatherboard of a barge. The fish of course turns "broadside on" to the stream, and it would be no easy matter to bring to land even a board or other inanimate substance by means of a line so attached. Add to this the liberty of breathing enjoyed by the fish, the absence of interference with the free play of his gills, and the odds in his favour may be more readily conceived than calculated.

Under such circumstances a fish must of necessity take a long time in killing; but there must be something essentially wrong in the system of fishing when eight, ten, or even twelve hours are occupied, which is not unfrequently the case, in the capture of a single fish. 
I will transcribe for the benefit of my readers an abridged account of the killing of a fish thus hooked, with which my friend Mr Tyler favoured me while fishing on the - water, and which shows the occasional advantage, before referred to, of having two flies up. Mr Tyler, I should say, although a worthy, is essentially a prosy individual; he tells stories of intolerable length, in which the point bears the same proportion to the verbiage as Mercutio's two grains of wheat did to the bushel of chaff. Omitting incessant "I says" and "says he," and much other surplusage, the narrative ran as follows-(I had been detailing the account, as recorded in "Land and Water," of Miss Lloyd's twelve hours' struggle with a salmon):- "I 'll no say but that if a beast be foul heukit he may gi'e an awfu' deal of trouble an' tak' a deal of killin'; but twa hours!-hoo! hoo!! -it 's joost nonsense! Did I ever tell ye of a ploy I had on this varra pool wi' one of those foul-heukit gentlemen? (Let oot a wee bittie mair line.) Weel, it was last spring; I wor oot at five o'clock, an' Duncan Gilroy the precentor-(that's line eneuch oot)-had joost askit to hae a throw for a fash-(canny noo! yon's a grand bit for a saumon) -an' I allowed him. Weel, he fashed the stream abune, an' he fashed the pool doon to this varra stane we're noo on, an' 
deil a fin he moved-(yon wor a bad cast-do it again) - so I said, 'Duncan, lad, gi'e me the wandye 're better at psalmody than saumon-fishing ;' so I joost cast ower yonder big stane where the whirlie is. (That was a grand cast, I'm 'maist sure ye rose him then-bide a wee and try that ane again.) Weel, he rose at the bob an' I heukit him; it wor a grand rise, an' I felt I had him fast-a big fash he was, an' clean run, an' varra unaccommodatin' he showed himself, for deil tak' him! he wad gang na gait but his ain, an' that aye the wrang ain. (There he came agen! ye didna touch him; let me change the flee for ane a wee bittie smaller, an' gi'e him time to turn himself round.) Aweel I had him on mebbe ten minutes, an' he was beginning to come in, when Duncan, who I'm thinking was more handy wi' the gaff than wi' the rod, stept into the water an' tried to cleik him as he hung on the stream. Weel, he joost missed him, an' the fash made a dash doon-stream. I thocht he was clean lost for gude an' a', but he wasna', he was on fast eneuch; but siccan an' uncanny brute I never had to deal with-he was bad before-he was ten times worse now, an' it was twa good hours before Duncan stuck the cleik intil him, an' then I found that he had broken the bob out of his mouth, an' 
the tail fly had stuck into his gill as he made off. Nae wonder he was strong, for he was aughteen pund weight, clean run, an' I don't think that ane of the kye yonder, heukit in the same manner, could ha'e pulled much stronger. (Aye, mon! ye ha'e him noo!)"

We have storms in England, storms in London, when umbrellas are turned inside out, old ladies blown against the lamp-posts, and falling chimneypots make pious sailors thankful that they do not exercise their calling on such a dangerous element as the land ; but such storms as these are Zephyr's play when compared with the storms that visit the wild Western coast of Ireland: the waves of the Atlantic come rolling in, each a mile or more in length, and of an unknown altitude, dashing themselves against the everlasting rock with a force which would be irresistible, were it not exerted against the immovable, then resolving themselves into harmless spray, flung five hundred feet into the air, or forming huge balls of foam, which bound across the country like boys' footballs forty times magnified. Further inland the mighty wind, divided but not conquered by opposing headlands, rushes down through gorge and valley in impetuous blasts, the more dangerous that they come from all sorts of unsuspected quarters and 
uncalculated directions, lashing the waters of the lakes into no despicable resemblance to those of the mighty ocean. I have known a heavy boat, two or three tons weight, which had been laid keel uppermost on the strand, lifted bodily into the air, like one of Mr Home's mediums, and dashed down two hundred feet off, breaking in its descent every oaken rib in its body. I have known sheep blown from the rock on which they were feeding and drowned in the lake below. I have seen the waters collected in the form of a wheel, whirled round and carried upwards a hundred feet or more, and then descend in a mass sufficient to swamp a boat. For lake-fishing, especially salmon-fishing, the weather cannot be too wild, the water cannot be too rough; and it was on one of the wildest and roughest of days that my friend $G$. H., one of the best fishermen who ever threw a fly, and myself, accompanied by Captain H. as our Palinurus, embarked on the "Black Lake." We had scarcely a mile to row to our fishing-ground, but it was considerably over an hour when we reached it. But for the excitement, it would have been wearisome to mark the bunch of heather or the black stone precisely opposite to which, for some five minutes, despite the strongest efforts of our men, we would pitch and toss, apparently without gaining an inch 
There were odd points of rock which took longer time to weather, the wonder being that we ever got round them at all.

"It was by dint of passing strength, We reach'd our fishing-ground at length."

The stern, the post of honour, was kindly and considerately allotted to me. I do not think I could have fished from the bow, as my more accustomed companion did; besides which, I had the benefit of the Captain's advice and Tom Roy's comments. Tom is a character in his way: he loves me because I bring him 'baccy, and will fish on against all odds of wind and weather; he adores "Master George,"-it was himself that taught "the young idea" how to fish; and he reveres "the Captain" as the chief of all sportsmen. "Sit down, yer honour, or ye'll be tossed out of that entirely! Sit down, Master Gaarge, and don't mind how ye play yer fly; sure it's the water will do all the work and cost ye nothing. Master Gaarge! Master Gaarge!" with a yell, "he came at ye then-aisy now! back all of ye! BACK, I say!" No eye but that of a practised fisherman could have seen the break in that wild waste of waters, but Tom was right, and as, after about five minutes' hardest pulling, we regained the spot from whence we had drifted in about ten seconds, a sub- 
dued grunt of satisfaction told that a fish was hooked. The Captain, so placid before, was all excitement. "Pull out! pull in! pull away from the rocks! easy in the bow! pull Mick! pull Tom!" then to me, "Get your line in! wind up! wind up, or you 'll be entangled!" For once I did not obey with that readiness which I generally exhibit where orders are given the authority of which I recognise. One more cast I could not resist-I made it, and I too was "stuck in a fish." Then the wild excitement was at its height: the salmon rushed hither and thither, the reels sung, the lines ran out, the boat pitched and tossed more madly than before, the Captain shouted, the men hurraed and bent to their oars till they quivered again, and the spray dashed over the bows in a torrent. The fear of course was that in their reckless dance the fish, instead of harmlessly " poussetting" to each other, should perform a "chasser croiser" figure, hands across and back again, and so double the lines one on another, and inevitably escape. I confess that for a minute or more there was not that unanimity of action or counsel which ought to prevail in great emergencies. "Let him run!" shouted the Captain. "Howld him hard, Master George!" screamed Tom, "give him line, yer honour! hold up your hand! drop your point! 
you'll lose him! pull in to the rocks! pull out of the weeds! aisy, or he'll be under the boat! holy mother! but that was a great jump! pull away now, he's under the boat!" and amid half a dozen other contradictory orders and cautions, we were borne round a jutting rock, over which a friendly ash stretched its light stem and enabled my companion to obtain a secure hold on the slippery rock. Leaving him to fight it fairly out by himself, the boat's head was turned towards the middle of the lake, and it was not till we were a hundred yards from the shore, that, all chance of entanglement being over, I breathed freely and calmly set my wits and sinews to work in opposition to those of the deluded salmon. It were tedious to narrate the various efforts of the fish to escape. Once hooked in open water clear of weeds and rocks, if the fish get off, the man must be a muff; and in less than fifteen minutes from the time we left the shore, a beautiful salmon of thirteen pounds weight, well shaped and fresh run from the sea, was gasping at the bottom of the boat. We reached the shore just in time to gaff the other fish, and that half hour lives in my memory "albo lapide notata."

No treatise, however lucid or comprehensive, can by any possibility, without practice, make a 
Insherman; but the tiro will undoubtedly be better able to profit by the lessons which he will at first be perhaps somewhat roughly taught, if he bear in mind some hints which I am endeavouring to implant; at any rate, he will not, or should not, be entirely taken by surprise at the manœuvres of a hooked fish, if he has had patience to wade through these pages.

There is nothing more wonderful in nature than the similarity, nay, the identity, of the means adopted, under similar circumstances, by all animals to escape the danger which immediately threatens them.

"When the hound's in the green wood,

The deer keeps the hill;

When the gled's in the blue sky,

The laverock lies still."

When the mole disturbs the ground, the worm rushes into the light of day; when the hedgehog is assailed, it curls itself up; the squirrel, under like circumstances, seeks the tree; the rabbit, its hole; while the hare scuds across the country trusting to show her pursuer a fair pair of heels. These are the natural modes of escape from natural enemies; but how is it that a salmon, nay, a grilse, under similar circumstances, almost invariably practises similar, and by no means simple, 
mancuvres to escape from what must be considered an artificial shape in which danger is presented, and of which the creature can have no experience, and those manœuvres always admirably adapted to the end in view? One of the commonest and most effective of these, especially when you are fishing with a long line, is to run in directly towards you, thereby loosening the line and gaining the opportunity of shaking the hook out of its mouth. You must, at any risk, at any sacrifice of dignity; prevent this. Run backwards, throw the point of your rod well behind you, wind up in mad haste, do anything except pulling the line through the rings with your hand, as practised in Thames fishing. This may answer with a phlegmatic barbel, or a sulky pike, but never with the astute, vigorous salmon. Wind up! wind up !! wind up !!! Your reel, if made as recommended, with an extra large cylinder, will aid in this; but rapidity of motion is the great point, and unless you succeed in giving check by regaining a tight line, the fish will assuredly checkmate you and be lost. A lightly-hooked fish will invariably shake, flounder, and jump repeatedly into the air : your effort must be, by a light, firm, unswerving pressure, to fix the hold, and in this your pliable rod will greatly assist; but nerve is everything. If you are fright- 
ened-and it is no reflection on your courage to say you may be-not you, but the jumping fish is lost.

Another mode, equally efficacious, must have been handed down traditionally from salmon to smolt, or how should the latter, when he arrives at salmon estate, practise it as though he had been hooked every day of his life? Rushing downstream, taking out fathoms of line too freely given, the crafty savage returns on his tracks, swimming deep down in the bed of the stream, and trusting to the weight of the water to belly out the line and leave the fisherman under the mistaken impression. that the intended victim is still pursuing a downward course, the fish eventually brings such a strain upon the line that either it or the rod, or perhaps both, give way, and the finale is announced by the bright vision of Salmo saliens some twenty yards up-stream. To prevent this, you must ever be chary of giving out line ; use your legs as well as your arms; keep as nearly opposite to your fish as you can; and when constrained to lend him line, take it back with as much usury as your conscience will allow. As in every other pursuit, well begun is half done, and a fish well struck may be said to be half killed. Striking is a delicate and artistic movement, and, to be effective, must be made with some degree of variation, according to 
time and place. As a rule, you can hardly strike too lightly, and hardly strike too slowly. The formula I have before enunciated-One, he comes up! two, he goes down! three, you strike! is invaluable. It is like Mr Jorrocks's specific, " counting twenty" when a fox broke before he hallooed. More salmon, we venture to say, are lost by too quick striking than by any other error, and next to that, by too hard striking: a short, sharp turn of the wrist is all that is required. If the hook has struck on a reasonably soft part of the mouth, the barb of the hook will be covered, and that is all that is requisite; if the point of the hook has struck upon an impenetrable bone, the harder the blow, the more likely it is to rebound innocuously.

In the autumn, when the fish run larger, and are comparatively far more sluggish than in the summer, we hold striking to be entirely superfluous, nay, mischievous. Fish deep, wait till you feel a "tug," and then tighten your line. Your fish has hooked himself, and all you have to do is to kill him-if you can. It is usual, no doubt, to lay down arbitrary rules respecting wind, water, and weather, to be conscientiously observed by fish for your especial gratification, but I have found them remarkably and unjustifiably independent on all these points. As in the case of scent, the longer a 
man hunts, the less he admits he knows about the rules which govern it; so, the longer he fishes, the more readily he acknowledges his ignorance of the moving causes which affect the fishes' inclinations, or, as I contend, appetites. When the water is low, bright, and clear, it is useless fishing with a fly ; but I attribute this more to the impossibility of concealing yourself and disguising your operations than to any other cause. Under such circumstances, salmon are frequently taken with a great coarse lob-worm, at which a chub or a carp would turn up his nose. The most favourable state of the water for fishing is when the river is tolerably high, and neither rising nor falling rapidly, coloured, but not too deeply, and cold rather than warm. Soft winds, however essential in trout-fishing, are by no means desirable when the salmon is your object; and I think the best sport I have ever had has been with an easterly wind blowing. Still, as I have said, there is no golden rule, and your most experienced fisherman will be a better judge of the appearances of water and weather when he returns at night than when he went out in the morning.

In a rocky stream, whether the rocks are submerged or jut out from the bank, nothing is more common than the loss of your fish from the casting- 
line being "cut" by the sharp edges against which it is forcibly dragged. Not unfrequently, too, the salmon will run round a rock which projects sufficiently far into the water from the opposite side to allow of his doing so, thereby getting a dead pull at the line and breaking away. In such a case, when you feel the strain on the line relax, by no means give up the game as lost. Pass over, or, better still, let your attendant pass over to the other side, quietly release the line, and it will not unfrequently happen that the fish is still firmly attached to it; he, too, has felt the relief from the strain, and is quietly resting in fancied security after what he considers a release from unaccustomed and altogether incomprehensible labour. It must not, however, be supposed that all the salmon's manœuvres are premeditated or calculated as means to an end. We are apt to refine too much, and to attribute, without due consideration, reasoning motives to actions which originate solely in an instinctive avoidance of danger. A salmon runs your line against a sharp rock by pure accident, and not from malice prepense, with the express object of cutting it, although such result undoubtedly ensues. He runs round a rock because, terrified and excited, he knows not at the moment whither he is rushing, and frequently stops 
the moment he has gained the other side. As I have said before, his object seems to have been achieved, because from the absence of the strain he vainly assumes that it is so. In a rocky stream it is always advisable to use triple gut next to the hook, as though one strand may be cut, the others will still hold; but, as a rule, I hold twisted gut in abomination, and invariably fish with three or four round sound links next the fly, which will be found strong enough, if properly handled, to land a shark. I have elsewhere compared the running of a fish with that of a fox, but the analogy would be more perfect if compared with that of a horse that has broken loose. A fox in a country full of small coverts, lanes, and spinneys, runs short and dodges, because he wisely expects thereby to bewilder his pursuers. A salmon in a confined rocky stream runs short and dodges about for the same reason that a horse in a confined space runs short and dodges about; he is afraid of running against or upon the opposing obstacles. Give the runaway horse a free open plain, and he stretches away at full speed; give the salmon an extent of free open water, and he will run you out all the line you will permit, and frequently a great deal more than you ought to permit; indeed, the great secret in killing a salmon is to restrict him as far as possible in the 
article of line; hardly a manœuvre he practises, "seu ratio dederit seu sors objecerit," but is based upon that fallacy-too much line out. Of course there are situations in which you have no alternative but to trust to the effect of unlimited concession and give unlimited rope, in the hope that the fish will hang himself. You may be standing upon an isolated, slippery rock-you may be fishing upon one side of an island when your fish perversely runs up or down the other-you may be unable to follow him through the particular arch of a bridge he affects; but all these contingencies must be endured or met as they arise. I have said somewhere, in talking of riding at a fence, that there are some fences you must ride at slowly; some you must ride at rapidly, but that there are none that you should ride at with a loose rein. I had almost said the same with regard to the line holding a salmon, but there is a case in which a loose, nay the loosest, line affords the best chance of killing your fish; this is when the pool in which you are fishing empties itself by a rapid, perhaps impassable fall or torrent. At the very brink of this, on the "torrent's smoothness ere it dash below," your fish will frequently pause, hang motionless for several seconds, uncertain whether he should bear here above "those ills he has," or seek below those 
"he knows not of." In the boiling water, the sharp rocks, and the headlong fall, a breakage is almost certain, and your mind is bent upon preventing it. Now, salmon, in private life, doubtless, differ in character and disposition; but when in public, they invariably manifest a decided objection to being either led or driven, and if in any way they can make out what you wish them to do, they won't do it. When the fish is poised in the situation I have described (recollect he always descends a rapid tail-foremost), if you pay out your line hastily and liberally, it will be carried by the stream far behind him, and effect a very strong pull in a downward direction. The fish takes the hint and rushes upwards exactly as you desired; and if you give him an opportunity of retrieving his error it is your own fault. Should your manœuvre fail, and he persist in his original intention, the free line is all in your favour, as he never gets that dead pull which, in the heavy rapid water, must of necessity be fatal.

I cannot conclude this chapter better than by giving a sketch of the natural history of the salmon, a creature about which more has been written and less is accurately known than almost any other.

The ova are deposited in their gravelly bed during the winter months, principally November 
and December. They are hatched in about eighty days, according to the temperature of the season. Salmon occasionally spawn in the sea, but the eggs are never hatched there ; not unfrequently in lakes, but, except in those which fall and rise frequently and rapidly, the eggs perish. The fry in its early stage is barred, and improperly called a parr; the true parr- "Salmo samulus" of Linnæus, Yarrell, and many other authors-differs materially from the "salmon parr," but they are sufficiently like for confusion; and much confusion and much bitter discussion have ensued from the two fish being called by the same name. In the spring of the following year the young fish assume a silvery scale, and with the first May floods visit the sea as smolts. Some remain for a year or upwards in the salt water, but a large proportion return to the fresh water in the same autumn, invariably seeking the streams from which they went forth. They are then called "grilse," or "peel," and run from two to five and six pounds in weight. The male salmon is called a kipper, the female a baggit, after spawning both are called kelts. In this state they are poor and out of condition, and terribly voracious. They may be taken in any numbers by any kind of bait, but are always bad food, and until "weel mendit" show little sport. In Tweed, how- 
ever, and rivers where food is abundant, they apparently recover their condition, and for a short time before returning to the sea, which they continue to do until the middle or end of May, they are as strong and vigorous, and show as much sport, as a fresh-run fish, frequently more. The kelts are protected by law, but oddly enough the baggits, though on the eve of spawning, may be killed with impunity.

Next to poachers, who destroy the fish on the spawning-beds, and the bad sportsmen, who kill the female on her way thither, the worst enemies the salmon has to contend with are of its own race. The old kelts not only drive the young ones away, but fight among themselves to the death, and hundreds, ray thousands, float down the stream dead from the spawning-beds every year. The baggits have a clumsy knack of selecting their beds where others have been before them, and a very large proportion of the early-sown seed is destroyed by being routed up to make room for the later and less valuable deposit. The larvæ of dragonflies and other insects infest the spawningbeds, and destroy vast quantities of eggs. I am not aware of any other serious danger to the egg than the above. It is true that both the common and bull-trout devour them with avidity, and wait in large numbers immediately below the spawning- 
beds for that purpose, but they can only operate upon the light, unfecundated eggs which float down, or such as have not been covered by the gravel, or those which, after having been deposited, are routed up again as before-mentioned, and none of which could, by possibility, ever be hatched. The greatest benefit that can be bestowed on a river is the establishment of hatching-pools, to which the ova may be removed, and out of which the young are allowed to escape so soon as they have absorbed the little sack of nutriment provided by nature for their sustenance while in the baby state. It is waste of time and money to keep them longer.

The amended legislation which, in my humble opinion, is required to insure the enormous increase of this invaluable fish would provide for the shortening of the annual close-time for rods, and the lengthening of the weekly close-time for netstwelve hours extra for the latter would make an immense difference, and the closing of the nettingseason should vary according as the rivers are late or early ones. (The fishery inspectors, however, have so admirably argued this point, that I need not insist upon it.) Rod-fishing, either for trout or salmon, should be absolutely prohibited from the end of November to the Ist of March; no gaff should be used after the Ist of September at latest; 
and the barbed gaff, one of the most pernicious poaching implements in use, should be absolutely prohibited. Enlarged powers of entry on lands and searching suspicious persons should be given to water-bailiffs and keepers; and if fine and imprisonment were awarded to the purchaser as well as to the vendor of fish killed out of seasonto the receiver as well as to the thief-we should soon see our rivers, the impurities and obstacles being removed, as well stocked with fish as in the days when the mythical apprentice objected to having salmon more than three times a week. No salmon, excepting such as are demonstrably imported from Holland or elsewhere, should be allowed to be sold from Ist November to Ist March; after that date the sale might be free. No doubt there are plenty of kelts in the river; but a well-mended kelt is in no respect unwholesome, and not one person in a thousand knows him from a clean fish. It is absurd to legislate for individuals, and the public would soon learn the difference, though now in ignorance, and in the meantime little harm would result from the destruction of a few tons of what are, after all, for the time, barren fish.

THE END. 



\title{
"A Book for the Naturalist and Sportsman."
}

\section{New Edition, Price 5s., \\ FLOOD, FIELD, AND FOREST. \\ BY. GEORGE ROOPER.}

\author{
CONTENTS. \\ I. Autobiography of Salmo Salar, EsQ. \\ II. A Fox's TALE. \\ III. BOLSOVER FOREST. \\ IV. THE BAGMAN.
}

\section{OPINIONS OF THE PRESS.}

"A small volume is here recommended, not only to the sportsman but to the general reader, which while it deals with all field sports-even with the rat and the badger-and deals with them all lovingly as things of beauty and joys for ever, while it delights by the freshness of its story-telling, and ascends to high pathos in its incidents, is replete with a knowledge which nothing short of a life study can have given." - Fortnightly Review.

"The contents of this volume are formed in part of magazine papers which have already received the approbation of the sporting public, in part of original matter, which equally deserves to receive it. The two autobiographies of the salmon and the fox were much admired at the time for the freshness and vigour of the narrative, as well as for the knowledge they displayed both of natural history and field sports. In our judgment, however, the third portion of the work, now published for the first time, with the title of 'Bolsover Forest,' is the most interesting of the three, dealing as it does more particularly with that delightful border-land on which the sportsman and the naturalist meet. . . 'Bolsover Forest' is a history of bird's nesting, rat-catching, badger-hunting, snake-taming, and such other sports, partly juvenile, partly common to all ages, as he who has once tasted will always look back upon with pleasure."-Pall Mall Gazette.

"The real object of Mr Rooper's book is laudable. He wishes to make natural history more palatable than it is in general, and to avoid the didactic, stiff, statistical, quasi-scientific style of most writers. Not only does he succeed in this, but he has many other merits. He writes on sporting without exaggeration or vulgarity. Confining himself almost exclusively to what he has seen himself, he is at once original and accurate."-Spectator.

"Mr Rooper is one of those who has always steadily practised what he knows; and when we say that no method of capturing the birds, beasts, and fishes of his native land is unknown to him, and that he is willing to divulge all his secrets, we have probably said enough to recommend his book to all whom it may concern."-Contemporary Review.

"The volume contains four stories. . . They are charming from their fresh and healthy tone. 'The Bagman'.. is as good as anything of its kind by Whyte Melville, and this is the highest praise that can be. bestowed on any

'Foxiana.' "-Northampton Mercury. 
"This handsome, though not costly, volume is, in our judgment, a book of mark. .. 'Flood, Field, and Forest,' comprises several very clever and amusing tales, replete with interesting facts and incidents in natural history. . . . We must confess that (of course recognising a few well-known exceptions) we have almost despaired of seeing any one writing popularly upon hunting without vulgarity, or upon fishing without insipidity; but these tales are written by a man who is at once a keen sportsman, a quick-eyed diligent naturalist, and a gentleman; last, but not least, a practical master of good, simple, animated style, in whose compositions we detect no bad English, scarcely one slip-shod sentence or awkward expression. ... We repeat we feel a personal obligation to $\mathrm{Mr}$ Rooper for the pleasure his writings have afforded us." - i and and Water.

“'The Autobiography of Salmo Salar, Esq.,' 'A Fox's Tale,' 'Bolsover Forest,' and 'The Bagman,' are the headings of the four chapters which compose this volume, and in each the writer has striven with marked success to blend the description of facts in natural history with incidents such as fire the soul, and spur the imagination of the sportsman. . . A All sportsmen will enjoy reading it."-Daily Telegraph.

"We are all of us ready to be pleased with a good description of flood, field, and forest, and that the author has given us. Perhaps, with the exception of Whyte Melville, Mr Rooper is the best historian of a run with the foxhounds that we have had. . . . It has no doubt been a recreation to him to write the book; certainly it has been a recreation to us to read it." -Examiner and London Review.

"Mr Rooper may be credited with having accomplished his purpose in a manner that will render his book acceptable to young sportsmen, and highly popular with those who have a taste for natural history."-A thenceum.

"The object Mr Rooper appears to have in view is, to impart the knowledge which he has gained from his own experience to the unskilled tyro in handling the rod, the whip, or the gun; and whether he is giving his lessons in the guise of the salmon, the fox, or 'Master B.,' he equally contrives to render them both useful and entertaining."-Morning Post.

" 'Flood, Field, and Forest' is precisely the book it was meant to be, and may therefore be said to have attained perfection after its kind. . . . Even those who care little or nothing for field sports will find the book very amusing, and by no means unprofitable reading. ... Mr Rooper is evidently a master of his subject, from fox-hunting and salmon-fishing down to rat-catching and bird's-nesting, and his pages teem with information and useful hints for the benefit of novices." - The Echo.

"We need simply recommend to all lovers of sporting Mr George Rooper's 'Flood, Field, and Forest.'"-Daily News.

"The true excellence of the work rests in the author's powers of description, which are of no mean order."-Brighton Gazette.

"Mr Rooper has given us in this volume a very pleasant mélange of sport and natural history, full of fresh and spirited pictures of country life and English scenery. ... He writes in a genial and agreeable style, with a graphic power unusual among mere sporting men."-The Australian.

"Mr George Rooper has deservedly arrived at the second edition in his

Flood, Field, and Forest,' and as there are many readers of sporting works, we can recommend them this. The Helluo Librorum, among many tit-bits, will find in Mr Rooper's pages some most pleasant writing about field-sports, and a rattling description of a run with the hounds, which excels similar works by other eminent hands." - The Graphic. 


\section{CATA LOGUE}

or

\section{CASSELL, PETTER, \& GALPIN'S}

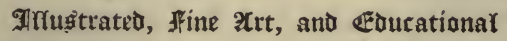

\section{P U B L I C A T I O N S.}

Atsop's Fables. A New and carefully revised Version of these Fables. By J. B. RUNDELL. Profusely Illustrated with Original Drawings by ERNEST GRISET. Cloth gilt, gilt edges, 2 Is.

Arms and Armour, in Antiquity and the Middle Ages; also a Descriptive Notice of Modern Weapons. Translated from the French of M. P. LAcombe, and with a Preface, Notes, and One Additional Chapter on Arms and Armour in England, by Charles Boutell, M.A., Author of "English Heraldry." Cloth, gilt top, 7s. 6d.

ATLASES. British Atlas, of 122 Maps, consisting of the Counties of England and Wales, with Divisional Maps of Scotland and Ireland. Bound in cloth boards, $f^{I}$ IOs. ; in half-morocco, $£_{2}^{2} 2 \mathrm{~s}$.

Folio General Atlas, consisting of 60 Maps of the Countries of the World. Strongly half-bound, $18 \mathrm{~s}$.

Folio County Atlas, containing 5o Maps of the Counties of England and Wales. Strongly half-bound, $18 \mathrm{~s}$.

Belle Sauvage Library, The. A Series of Volumes for Family and Home Reading. Handsomely bound in bevelled boards, red edges, price 3s. $6 \mathrm{~d}$. per volume.

1. Pulpit Table Talk. Containing Remarks and Anecdotes on Preachers and Preaching. By EDWIN B. RAMSAY, M.A., LL.D., F.R.S.E., Dean of Edinburgh.

2. The Search for the Gral. By Julia Goddard, Author of "Joyce Dormer's Story," "Adriana," \&c., \&c.

3. Sermons for Boys. By the Rev. Alpred Barry, D.D., Principal of King's College, London, late Head Master of Cheltenham Grammar School.

4. The Life of Bernard Palissy, of Saintes. By Henry MORLEY, Professor of English Literature in University College, London.

5. The Young Man in the Battle of Life. By the Rev. Dr. LANDELS, Author of "Woman: her Sphere," \&c.

Other Volumes in preparation. 
BIBLES. Cassell's Illustrated Family Bible. Complete in One Volume, in cloth, gilt edges . • Ł I II 6 Ditto. Two equal Volumes, ditto $\quad$ : $\quad$ I I5 Ditto. One Volume, in calf, gilt edges : $\quad$ - 2 ro Dtito. One Volume, in morocco antique . . 3 ro o Cassell's Illustrated Family Bible. Toned Paper Edition. Half-morocco, gilt edges, $£^{2}$ Ios. ; full morocco antique, $£ 3$ Ios.; best full morocco, flexible, elegant, $£ 3$ i5s.

Cassell's Illustrated Family Bible. Large Paper Edition. Cloth gilt, $£^{2}$ ros. ; flexible morocco antique, $£ 4$.

The Child's Bible. Large Print; Large Pictures. Being a Selection from the Holy Bible, in the words of the Authorised Version, with large full-page Illustrations, especially designed for Children, by the best Artists of the day. Cloth, elegant, gilt edges, $\ell_{\mathrm{I}}$ Is. ; flexible leather binding, hand tooled, gilt edges, $£ \mathrm{I}$ Ios. ; best morocco elegant or antique, $£ 22 s$.

The Holy Bible. Illustrated by Gustave Dorḱ. Complete in two very handsome volumes. Small folio, bound in cloth, gilt, $£ 8$; morocco, gilt edges, $£ 12$; best polished morocco antique extra, $£ \mathrm{I} 5$; Divisional Vols. I. to VIII., each $f_{I}$ Is.

Bible Dictionary. Complete in One or Two Volumes, strongly bound in cloth, 2 IS. ; in one volume, strongly bound in russia or morocco, 40 .

Biographical Dictionary. Edited by T. Teignmouth Shore, M.A.

Book-Keoping, by Single and Double Entry. Cloth, Is. Ruled Account Books to ditto, extra, Is. 6d. each Set.

Book-keeping for the Million. By Theodore Jones. 2s. ; cloth, $3 \mathrm{~s}$.

Book-keeping for Schools. The English System. By THEODORE JONES. 2s. ; cloth, 3s.

The Key to. 2s. ; cloth, 3s.

Books for Jones's Systems, Ruled Sets of. 2 s.

Book of Birds. Edited by T. Rymer Jones. Monthly Parts, price $7 \mathrm{~d}$.

Book of Martyrs. Edited by the Rev. W. Bramley-Moore, M. A. Illustrated with full-page Designs by the best Artists. Imperial 8vo, cloth. Bound in plain cloth, I2s.; bound in full gilt cloth, gilt edges, $15 \mathrm{~s}$.

with Engraved Frontispiece, 252 pages, price One Penny. Also Special Editions of the same, in cloth, limp, 4d.; or cloth, gilt edges, $6 \mathrm{~d}$. 
Book of Historical Costumes, The, drawn from the best Specimens and most Authentic Documents of each Period. With 96 full-page Coloured Engravings. Cloth, gilt edges, 50 .

Brahma Fowl, The. By L. Wright, Author of the "Practical Poultry Keeper." Imperial 16mo. Illustrated with Four Chromo-Lithographs from Life. Cloth, lettered, $5 \mathrm{~s}$.

Brewer's Series of First Books. Price 6d. each.

Reading and Spelling.

Bible History.

History of England.

Geography.

Science.

Common Things.
French History.

Astronomy.

Chemistry.

Facts and Discoveries.

Grecian History.

The History of Rome.

Brewer's Guide to Every-Day Knowledge. 2s. 6d.

The Young Tutor. First Series, 3s. 6d.

Ditto. Second Series, 3s. 6d.

British Army, The History of the: its Origin, Equipment, and Progress. By Sir SibBald David ScoTT, Bart. Dedicated, by special permission, to the Queen. One Hundred Illustrations. Two volumes, bound in cloth, $£ 2$ 2s.

British Museum, a Handy-book of the, with upwards of 150 Illustrations of the most interesting Subjects, and full Historical and Descriptive Letterpress by T. NICHOLS, a Senior Assistant in the Principal Librarian's Office, British Museum ; Author of "The Hand-book for Readers." Demy 8vo, 400 pages, cloth, lettered, 2 Is.

Burritt, Elihu. Thoughts and Notes at Home and Abroad. Cloth, $6 \mathrm{~s}$.

Old Burchell's Pocket. A Book for the Young Folks. Eight Illustrations. Cloth, lettered, 3s. $6 \mathrm{~d}$.

Cameron's Lectures on Health. Cloth, 2s. 6d.

Captive Missionary, The. Being an Account of our Imprisonment and Sufferings in Abyssinia. By the Rev. H. STERn, one of the Captives. Demy 8vo, cloth, 2Is.

Chemistry of Food; or, the Stock Feeder's Manual in Relation to the Breeding and Feeding of Live Stock. By C. A. CAMERON. Cloth, 5 s.

CHILDR EN'S LIBRARY. New and Original Works. Uniform in size and price.

The Children's Album. Containing nearly Two Hundred beautiful Engravings, with Short Stories by UNCLE JoHN. Fourth Edition, 21st Thousand. Square crown 8vo, 368 pages, cloth, gilt, 3s. 6d.

Peggy, and other Tales ; including the HISTORy OF A THREePENNY BIT, and the STORY OF A SOVEREIGN. With Eight Illustrations. Handsomely bound in cloth, gilt, $3^{\text {s. }} 6 \mathrm{~d}$. 


\section{CHILDREN'S IIBRARY-(continued).}

Old Burchell's Pocket: A Book for the Young Folks. By ELIHU BURRITT. Illustrated with Eight Engravings. Bound in cloth, gilt, $3 \mathrm{~s}$. $6 \mathrm{~d}$.

Mince-Pie Island: A Christmas Story for Young Readers. By R. ST. John Corbetr. Handsomely Illustrated. Cloth, gilt, 3s. $6 \mathrm{~d}$.

Cloudland and Shrdowland: or, Rambles into Fairy Land with Uncle White Cloud. Beautifully Illustrated. Bound in cloth extra, gilt letters, $3 \mathrm{~s} .6 \mathrm{~d}$.

The Queen of the Tournament, and Butterfly Ball at Maperley Hall. By the Author of "Mince-Pie Island." With Eight Illustrations by F. LAwson. Cloth extra, gilt lettered, 3s. $6 \mathrm{~d}$.

Iily and Nannie at Sohool: A Story for Girls. By the Author of "The Little Warringtons." Illustrated by DALziel. Brothres. Cloth extra, gilt lettered, 3s. $6 \mathrm{~d}$.

The Magic of Kindness; or, the Wondrous Story of the Good Huan. By the Brothers MAYHEW. With Illustrations by WALTER Crane. 3s. $6 \mathrm{~d}$.

On a Coral Reef: A Sea Story for Boys. By Arthur Locker. Handsomely Illustrated. 3 s. 6 d.

Crocker the Clown: A Tale for Boys. By B. Clarkr, Editor of "Kind Words." Handsomely Illustrated. 3s. 6d.

King Gab's Story Bag ; and the Wondrous T'ales it contained. By Heraclitus Grey. With Illustrations by Walter Crane. 3s. $6 \mathrm{~d}$.

Hours of Sunshine: A Series of Poems for Children. By MatThias BARR, Author of "Little Willie," \&c. With $x 6$ Coloured Plates from Designs by Oscar Pletsch. 3s. 6d.

Playing Trades. By Heraclitus Gkev, Author of " King Gab," \&c. With 16 Coloured Plates, from Designs by J. BARFOOT. Cloth, gilt, 3 s. $6 \mathrm{~d}$.

ONE SYLLABLE SERIES.

Aisop's Fables, in Words of One Syllable. With Illustrations printed in Colours by KRONHEIM. Handsomely bound in cloth, gilt, 3 s. $6 \mathrm{~d}$.

Sandford and Merton, in Words of One Syllable. With Illustrations printed in Colours by Kronherm. Handsomely bound in cloth, gilt, $35.6 \mathrm{~d}$.

Reynard the Fox; the Rare Romance of, and the Shifts of his Son Reynardine. In Words of One Syllable. By SAMUEL Phillips Day. With Coloured Illustrations by Kronherm, from Designs by ERnest Griset. 3s. 6d.

The Pilgrim's Progress. Done in Words of One Syllable by S. Phillips Day. With Coloured Illustrations by KRONHEIM. 3s. $6 \mathrm{~d}$.

The Swiss Framily Robinson. In Words of One Syllable. By the Author of "The Boy's First Reader." Coloured Illustrations from Designs by GRISET, CRANE, \&c. 3s. 6d.

Fvenings at Home. In Words of One Syllable. By the Author of "The Children's Album." Coloured Illustrations from Designs by Downard, BAYes, \&c. 3s. 6d. 
Coloured Cards. Shilling Packets. Three Sorts. Animals of all Climes - Feathered Creation - Floral Beauties of the World.

Commentary, Matthew Henry's. Complete in Three Volumes. Demy 4to, cloth lettered, $£^{2}$ I 2s. 6d.

on the Old and New Testaments. By Matthew HENRY. A New and Illustrated Edition, with additional Notes, Critical, Historical, and Geographical ; together with a Life of the Author. Divisional Vol. I. Royal 4to, cloth, lettered, 12s. 6d.

\section{DORÉ SERIES, THE.}

The Holy Bible. English Edition. Illustrated by Gustave DORÉ. Complete in two very handsome volumes. Small folio, bound in cloth, gilt, $£ 8$; morocco, gilt edges, E12; best polished morocco antique extra, £I5. In Eight Divisional Volumes, each 2Is.

Milton's Paradise Lost. Illustrated with full-page Drawings, by GUSTAVE DORÉ. With Notes, and a Life of Milton, by the Rev. Robert Vaughan, D.D. In one large folio volume, bound in cloth, $£ 5$; best polished morocco, gilt extra, £

Dante's Inferno. English Edition. Illustrated by Gustave Doré. Translation by the Rev. H. F. CARy, M.A. Crown folio, bound in cloth, $£ 2$ IOs.; bound in morocco antique, with gilt edges, $£ 445$. ; elegantly bound in full morocco, $£ 66 \mathrm{~s}$.

Dante's Purgatory and Paradise. English Edition. Uniform with the INFERNo, and same price.

Don Quixote. English Edition. With about 400 Illustrations by GUSTAVE DORÉ. In one handsome quarto volume, cloth, $£^{1}$ IOs. ; ditto, bound in half-morocco, $£ 2$ 5s.; ditto, bound in full morocco antique, $£ 3$ ros.

Atala. By Chateaubriand. English Edition. Illustrated by GuSTAVE Doré. Folio, cloth, $£^{2} 2$ s. ; bound in morocco gilt, $£ 44$ s.

La Fontaine's Fables. Illustrated with full-page Drawings by GUSTAVE DORÉ. In one handsome quarto volume, cloth, $£$ I IOs.; ditto, bound in half-morocco, $£^{2} 5$ s. ; ditto, bound in full morocco antique, $£ 3$ Ios.

The History of Croquemitaine, and the Times of Charlemagne. Illustrated throughout by GusTave DORÉ. The text freely rendered from the French by ToM Hood. Imperial 4 to, $£^{\prime}$ Is.

Fairy Realm. A Collection of the Favourite Old Tales. Illustrated by GUSTAVE DORÉ, and told in Verse by ToM HooD. Imperial 4to, $£_{I}$ IS. 


\section{DORÉ SERIES, THE-(continuea).}

The Adventures of Munchausen. Illustrated by Gustave Doré. 4to, cloth, IOs. 6d.

The Legend of the Wandering Jew. Twelve large Designs by Gustave Doré. Folio, ${ }_{15}$ s.

Eighteenpenny Series of New and Original Works. Bound in best cloth, gilt edges, with Four Coloured Plates by KRONHEIM in each Book.

The Holidays at Llandudno.

The Hop Garden: A Story of Town and Country Life.

Algy's Lesson. By S. E. De Morgan.

Ashfield Farm; or, Ellen and Robert's First Journey from Home.

Grandmamma's Spectacles. By the Author of "A Trap to Catch a Sunbeam."

Hid in a Cave; or, The Lost Child.

Little Fables for Little Folks.

Flora Selwyn : A Story for Girls.

** Other Volumes in active preparation.

England, Illustrated History of, from the Earliest Period to the Present Time. Complete in Eight Volumes, bound in cloth, 6s. and 7s. 6d. each. Ditto, Four Volumes, strongly bound in half-calf, with full gilt backs and cloth sides, £4. The cloth volumes can be had separate.

The Toned Paper Edition, Vols. I., II., III., and IV., bound in cloth; each 95 .

England's Great Commoners. Being Lives of Gladstone, Disraeli, and Bright. Cloth, lettered, 3s. $6 \mathrm{~d}$.

English and French Correspondence for Boys. I8mo, cloth, 2s. 6 d.

English and French Correspondence for Young Ladies. $18 \mathrm{mo}$, cloth, $2 \mathrm{~s} .6 \mathrm{~d}$.

Fnglish and French Commercial Correspondence. Cloth, 2s. 6d.

English Heraldry. By Charles Bovtell, M.A. With 460 finely engraved Illustrations. In One Volume, crown 8vo, cloth, 7s. 6d.

English Sea Watering-Places, Guide to. Paper covers, Is. ; cloth, Is. 6 d.

English Spelling and Reading Book. With upwards of 50 Engravings on Wood. New Edition. 8vo, cloth, Is.

Euclid, Cassell's : being the First Six Books, with the Eleventh and Twelfth of EUCL.ID. Edited by Professor WALLACE, A. M. of the Glasgow University, and Collegiate Tutor of the University of London. Crown 8vo, stiff covers, Is. ; cloth, Is. $6 \mathrm{~d}$. 
Euclid. Cassell's : Key to ; containing the Enunciations of all the Propositions and Corollaries. $32 \mathrm{mo}$, paper covers, $4 \mathrm{~d}$.

Family Prayer Book. Bound in plain cloth, 7s. 6d.; handsome cloth, with gilt edges, 95. ; morucco antique, 2 Is.

Farmer's Almanack. By J. C. MORTon. Published Yearly. Crown 8vo, is.

Farm Labour, Handbook of. By J. C. MORTon. 2s.

French, Cassell's Lessons in : containing a Complete View of the Idioms of the French Language, in a Series of Easy and Progressive Lessons. By Pro'essor Fasquelle. New Edition, revised and improved. By Professor DE Lolme. I2mo, Parts I. and II., in paper, 2s. ; cloth, each 2s. 6d. Complete in one volume, cloth, $4 \mathrm{~s} .6 \mathrm{~d}$.

Key to the Exercises in Cassell's Lessons in. I2mo, paper, Is. ; cloth, Is. $6 \mathrm{~d}$.

French Manual. Forming a Complete, Simple, and Practical Guide to a thorough knowledge of Speaking the French Language. By Professor De LOLME. Crown 8vo, cloth, 3s.

French Reader, The: containing Extracts from the Best Authors. Designed for the Improvement of Students in reading the French Language. New Edition. By Professor De LoLme. I $2 \mathrm{mo}$, paper, 2s. ; cloth, 2s. $6 \mathrm{~d}$.

French-English and English-French Dictionary. Composed from the French Dictionaries of the French Academy, Bescherelle, Landais, \&c. ; from the English Dictionaries of Ogilvie, Johnson, Webster, \&c., \&c.; from the Technological and Scientific Dictionaries of both Languages. By Professors De Lolme and Wallace. Demy 8vo, cloth, lettered, 7 s. 6 d.

Cheap Edition for Schools. Cloth, 3s. 6d. French, Shilling Lessons in. By Professor DE LoLMe.

French, Sixpenny Lessons in, with Rules for Pronunciation, on an entirely Novel and Simple Plan. Reprinted in a revised form. Crown 8vo, paper covers, $6 \mathrm{~d}$.

French History, My First Book of. By Dr. Brewer. 6d.

Galbraith and Haughton's Scientific Manuals. The high character of this Series is well known, as furnishing Text-books fur the Dublin University and numerous first-class Schools.

Arithmetic. Containing nearly 2,000 Examples. Cloth, lettered, 3s. $6 \mathrm{~d}$.

Plane Trigonometry. Cloth, lettered, 2s. 6d.

Euclid. Elements I., II., III. Cloth, lettered, 2s. 6d.

- Books IV., V., VI. Cloth, lettered, 2s. 6d. 
Galbraith and Haughton's Manuals-(continued).

Mathematical Tables. Cloth, lettered, 3s. 6d.

Mechanics. Cloth, lettered, 3s. 6d.

Optics. Cloth, lettered, 2s. 6d.

Hy'drostatics. Cloth, lettered, 3 s. $6 \mathrm{~d}$.

Astronomy. Cloth, lettered, 5s.

Steam Engina Cloth, lettered, 35. 6d.

Algebra. Third Edition. Part I., cloth, 2s. 6d. ; complete, cloth, lettered, 7s. $6 \mathrm{~d}$.

Tides and Tidal Currents. New Edition, with Tidal Cards. Cloth, lettered, $3 \mathrm{~s}$.

Natural Philosophy. With $x$ fo Illustrations. Cloth, 4s. 6d.

The Three Kingdoms of Nature. With numerous Illustrations. ros. 6d.

Gallery of Kings and Queens, The Royal. Embellished with Portraits of our English Sovereigns. Handsomely bound in cloth, crown $8 \mathrm{vo}, 2 \mathrm{~s} .6 \mathrm{~d}$.

German Reader, The International, for the use of Colleges and Schools. Containing Aids to Students, Selections from the best Prose Writers, and an Anthology of German Poetry. By EDWARD A. OPPEN, of Haileybury College. I2mo, cloth, 4s. 6 .

German, Lessons in; in a Series of Easy and Progressive Lessons. By W. H. Woodbury. Parts I. and II., I2mo, paper, 2s. ; cloth, each, 2s. $6 \mathrm{~d}$.

Complete in One Volume, cloth, 4s. 6d.

paper, Is.; cloth, Is. 6 d.

Key to. Revised Edition. I2mo,

German, Sixpenny Lessons in. By E. A. Oppen, Esq., of Haileybury College. Fcap. 8vo, paper covers, 6d.

German-Fnglish and English-German Pronouncing Dictionary, The. 8vo, cloth, 7s. 6d.

German Dictionary. Cheap Edition for Schools. 3s. 6d.

Goethe Gallery. A Series of beautiful Photographs from KaUlbaCH's Drawings of the Heroines of Goethe. Handsomely bound in morocco, $42 \mathrm{~s}$.

Goethe's Heroines. A Series of exquisite Engravings on Steel, from Designs by the great German Artist, W. KaulBaCH. With Descriptive Letterpress by George Henry Lewes. Cloth, lettered, $£ 77 \mathrm{~s}$.

Golden Leisures. By Wm. Gordon Smythies. Small 4to, Is.

Greece, The Scenery of. By W. Linton. Fifty exquisitely beautiful full-page Steel Engravings, with descriptive Letterpress. Handsome 4to vol., cloth lettered, gilt edges, $42 \mathrm{~s}$. 
Greece, the Poets of. By Edwin ARnold, M.A., Oxon; Author of "Griselda, and other Poems," \&c. Demy 8vo, 256 pages, 10s. $6 \mathrm{~d}$.

Greek, Lessons in. By the Rev. J. R..BEARD, D.D. I2mo, paper, 3s. 6d.; cloth, 4s.

Greek, The Acts of the Apostles in the Original. By JOHN J. OWEN, D.D. I2mo, cloth, 2s. 6d.

History of Julius Cæsar, The. By His Majesty Napoleon III. Translated under the immediate supervision of the Emperor himself. Vols. I. and II., 8vo, cloth, each, I2s.; printed on large paper, and half-bound in Roxburgh style, Vols. I. and II. each, 25s. Maps to the Text of each Volume, 5s. each.

Hood's Works. Vol. I. Cheap Edition. Cloth, lettered, 5s.

Hudson's Arithmetic for School and College Use, with a Copious Collection of Exercises, and Key. Cloth, limp, Is. $6 \mathrm{~d}$.

Illustrated Library, The. Plain cloth, 7s. 6d. ; full gilt cloth, gilt edges, IOs. 6d. ; morocco antique, $21 \mathrm{~s}$.

Cassell's Book of Sacred Poems. Illustrated. Edited by the Rev. R. H. BAYNes, M.A., Editor of "Lyra Anglicana."

Cassell's Illustrated Bunyan. The PILGRIM'S PROGRESS. Illustrated throughout.

Cassell's Illustrated Bunyan. The HOLY WAR. Illus. trated throughout.

Cassell's Illustrated Gulliver. GULLIVER'S TRAVELS. By DEAN SwIFT. Profusely Illustrated throughout by MORTEN.

Cassell's Illustrated Robinson Crusoe. Beautifully Illustrated throughout.

Cassell's Illustrated Readings. Conducted by Tом Hoop. In Two Vols., each complete in itself.

Goldsmith's Works, Illustrated. The VICAR of WAKEFIELD and POEMS. Illustrated throughout.

Illustrated Travels : a Record of Discovery, Geography, and Adventure. Edited by H. W. Bates, Assistant-Secretary of the Royal Geographical Society, and profusely illustrated by the best Artists of the day, from Drawings made on the spot. Royal 4to, cloth, 15s.; extra cloth, extra gilt, gilt edges, I8s.

Illustrations, Millais'. A Collection of Eighty Drawings on Wood, by John EveretT Millais, R.A. 4to, cloth, gilt edges, $16 s$.

In Memoriam the late George Housman Thomas. Being a series of carefully printed Wood Engravings, from Designs by Mr. ThомAS, with Descriptive Letterpress. Handsome 4to vol. Cloth, gilt, 2Is.

Jingles and Jokes for Little Folks. By Toм HooD. Illustrated. Boards, Is. 
Lathe, The, and its Uses ; or, Instruction in the Art of Turning Wood and Metal. Illustrated with Diagrams. Demy 8vo, cloth, lettered, I5s.

Latin Grammar, The. By Professors Andrews and Stoddard. Crown 8vo, cloth, 3s. $6 \mathrm{~d}$.

Latin Exercises. Adapted to Andrews and StodDard's "Latin Grammar." 12mo, paper, Is. 6d, ; cloth, $2 \mathrm{~s}$.

Latin Reader, The. Adapted to "Cassell's Latin Grammar ;" to which is appended an appropriate Dictionary. I2mo, cloth, Is. $6 \mathrm{~d}$.

Latin, Lessons in. By the Rev. J. R. BEARD, D.D. I2mo, paper, 2s. 6d.; cloth, 3s. Key to. 12mo, paper, Is.; cloth, Is. 6d.

Latin, First Lessons in. By Professors ANDrews and STODDARD. I $2 \mathrm{mo}$, paper, Is. ; cloth, Is. $6 \mathrm{~d}$.

Latin-English and English-Latin Dictionary, Cassell's. By J. R. Beard, D.D., and C. Beard, B.A. Cloth, 7s. 6d.

Latin Dictıonary. Cheap Edition for Schools. Cloth, 3s. 6d.

Little Songs for Me to Sing. Illustrated by J. E. Millais, R.A.; with Music composed expressly for the Work by HENRY Leslie. Square crown (Dedicated, by express permission, to Her Royal Highness the PRINCESS OF WALES), 6s.

Lovers' Dictionary, The: A Poetical Treasury of Lovers' Thoughts, Fancies, Addresses, and Dilemmas. Indexed with nearly Ten Thousand References. Crown 8vo, cloth, $5 \mathrm{~s}$.

Map of London, Great. In Nine Double Sheets, and on a Scale of nine inches to a mile. In a Wrapper, $5 \mathrm{~s}$ :

- On Rollers, I2s. ; with spring box, 25 s.

Environs. On rollers, 7s. 6 d.

Mission Life. A Monthly Record of Mission Work. Edited by the Rev. J. Halcombe. Price 6d.

Natural History, Cassell's Popular. Profusely Illustrated with splendid Engravings and Tinted Plates. Complete in Two Volumes, bound in cloth, 30s. Do., Two Volumes, half-calf, full gilt back, 45s. Do., Two Volumes, halfmorocco, full gilt, 50s. Do., with Coloured Illustrations, Four Volumes, bound in cloth, $42 \mathrm{~s}$.

Natural History of the Three Kingdoms, The. With Coloured Plates, and Text in English, French, and German. Oblong 4to, coloured boards, 3s. $6 \mathrm{~d}$. 
Natural Philosophy, The Elements of, for the Use of Schools. By the Rev. Samuel Haughton, M.D., F.R.S., Fellow of Trinity College, Dublin. Fully Illustrated. Bound in cloth, $4 \mathrm{~s} .6 \mathrm{~d}$.

Natural Philosophy, in Easy Lessons. By Prof. Tyndall. Cloth, lettered, 2s. 6d.

Hand-Book of. From the simplest Elements to the Phenomena of Electricity and Magnetism. Is.

Nature, The Three Kingdoms of. By the Rev. S. HAUGHTON, D.D. With numerous Illustrations. Cloth, lettered, Ios. 6 d.

Now Popular Educator. Revised to the Present Date, with numerous Additions. Vols. I., II., III. and IV. now ready, best cloth gilt, $6 \mathrm{~s}$. each.

North-West Passage by Land, The. By Viscount Milton, M.P., F.R.G.S., F.G.S., \&c., and W. B. ChEadLE, B.A., M.D. Cantab., F.R.G.S. 8vo, cloth, with Twenty-two full page Illustrations and Two Maps. Sixth Edition, 21s. Do., do., Smaller Edition, complete, with Eight Illustrations, crown 8 vo, cloth, $6 \mathrm{~s}$.

Old Friends and Now Faces. Demy 4to, cloth, elegantly gilt, with Twenty-four Full-page Illustrations, beautifully printed by KRONHEIM, 5s.

\section{Penny Library of Popular Authors.}

1. The Book of Martyrs. By Joнn Foxe. With Engraved Frontispiece, complete 252 pages, price One Penny. Also, Special Editions of the same, in cloth, limp, ${ }_{4}$ d., or cloth, gilt edges, $6 \mathrm{~d}$.

2. The Pilgrim's Progress. By John Bunyan. With Engraved Title and Frontispiece, complete, 384 pages, price One Penny. Also, Special Editions of the same, in cloth, limp, 4 d., or cloth, gilt edges, $6 \mathrm{~d}$.

Picture Natural History. A Series of Plates numbering upwards of 700, in which the Animal, Vegetable, and Mineral Kingdoms are classified in Families. With Descriptive Letterpress. Edited by the Rev. C. Boutell, M.A. $4^{\text {to, }}$ cloth, lettered, 5 s.

Picture Teaching for Young and Old: A Series of Object Lessons Progressively Arranged, so as to teach the meaning of every term employed. With more than 200 Illustrations. 4 to, cloth, lettered, $5 \mathrm{~s}$.

Popular Educator, Cassell's. Small 4to, in cloth boards. Six Volumes, each, 4s. 6d. In Three Double Volumes, each, 8s. 6d. Printed on better paper, per Single Volume, 5s. ; Double Volumes, 9s. Strongly bound in Three Double Volumes, half-calf, cloth sides, marble edges, $£^{2} 5 \mathrm{~s}$. The Volumes are sold separately. 
Practical Poultry Keeper, The. A Complete and Standard Guide to the Management of Poultry, whether for Domestic Use, the Market, or Exhibition. By L. Wright. Fourth Edition. With plain Illustrations, bound in cloth, 5s.; with coloured ditto, ditto, 6s. 6d.

Primary Series. An Entirely New and Original Series of Manuals, specially prepared with a view to meeting the want indicated by Her Majesty's Commissioners of Education in National and other Schools, by providing a series of simple treatises on the RUDIMENTARY BRANCHES of Education, written by first-class men, whose personal knowledge of what is actually wanted and whose practical experience render them peculiarly fitted to supply the specialité required. The following Volumes are now ready (others in preparation) :-

Elementary Arithmetic: dealing with the Primary Rules in a new and original manner, and supplying more than r, roo Examples. Cloth, lettered, $4 \mathrm{~d}$.-Key to ditto, cloth, $3 \mathrm{~d}$.

Elementary British History : a condensed recital of the Principal Events of British History, specially prepared for popular use in Junior Classes. Cloth, lettered, 6d.

Elementary Geography, written in a simple, terse style, and furnishing throughout the Etymology of Terms supplied. Illustrated. Cloth, lettered, $4 \mathrm{~d}$.

England at Home : An Elementary Text-Book of Geography, Manufacture, Trade, and Commerce. Cloth, lettered, rs.

Our Bodies: An Elementary Text-Book of Human Physiology : with roo Questions for Examination, and numerous Illustrations on Wood. Cloth, lettered, rs.

Our Houses, and what they are Made of : a familiar but scientific description of the materials used in the construction of our houses ; giving full account of the nature and origin of wood, iron, stone, \&c., with illustrative designs and descriptions of the various trades employed in their manufacture or manipulation. Cloth, lettered, rs.

The Uses of Plants in Food, Arts, and Commerce. With Illustrations. Is.

Right Lines in their Right Places; or, Geometry without Instruments : an entirely novel treatment, which explains to the youngest pupil the First Principles of Geometry. With Drawings on Wood by the Author. Cloth, lettered, rs.

The Boy's First Reader, in Words of One Syllable, with Spelling Lessons. Adapted to Standard I. Illustrated. Cloth, lettered, $4 \mathrm{~d}$.

The Boy's Second Reader. Adapted to Standard II. Cloth, lettered, $4 \mathrm{~d}$.

The Girl's First Reader, in Words of One Syllable, with Spelling Lessons. Adapted to Standard I. Illustrated. Cloth, lettered, ${ }_{4} \mathrm{~d}$.

The Girl's Second Reader. Adapted to Standard II. Cloth, lettered, 4d. 


\section{Primary Series-(continued).}

The Animal Kingdom, Explained in a familiar but strictly scientific manner. With abundant Illustrations. Double vol., cloth, lettered, $2 \mathrm{~s}$.

Right Words in their Right Places. An Elementary Grammar. Cloth, lettered, is.

Quiver, The: A Magazine for Sunday and General Reading. Volumes. for 1866, 1867, 1868, and 1869:-Each Volume handsomely bound in cloth, with plain edges, 7s. 6d.; or with gilt edges, 8s. 6 d.

Quiz, Sketches by. Consisting of "Young Ladies," "Young Gentlemen," and "Young Couples." Illustrated by "PHIz." Cloth, extra, lettered, 3s. $6 \mathrm{~d}$.

\section{Representative Biographies.}

Life and Career of Lord Brougham, with Extracts from his Speeches and Notices of his Contemporaries. 256 pages, $8 \mathrm{vo}$, cloth, is. $6 \mathrm{~d}$.

The Life of Benjamin Disraeli. xs. ; cloth, Is. 6 d.

The Life of John Bright. rs. ; cloth, is. 6d.

The Life of W. E. Gladstone. 1s. ; cloth, rs. $6 \mathrm{~d}$.

The Public tife of Queen Victoria. 8vo, 2s.; cloth, 2s. $6 \mathrm{~d}$.

San Juan Water Boundary Question. By Viscount MILTON, M.P. Cloth, Ios. 6d.

Schiller Gallery, The. A Series of exquisite Photographs from Kaulbach's Paintings of Scenery from Schiller. Cloth, lettered, $£ 55$ s.

Science Popularly Explained. Containing 4,000 Questions and Answers. New Edition, cloth, lettered, 3s. 6d.

Shakespeare, Cassell's Illustrated. Edited by Charles and Mary Cowden Clarke. Vol I. (Comedies), bound in cloth, I2s.; Vol. II. (Historical Plays), bound in cloth, IOS. 6d. ; Vol. III. (TRAGEDIES), cloth, I2s. 6d. The Complete Work, in three volumes, cloth, lettered, uniform, $£^{\prime}$ I5s. Half morocco, $£^{2}$ ros. The Separate Plays may be had, price Is. each.

\section{Shilling Story Books.}

Little Lizzie. By Mary Gillies. And other Tales. Is.

Iuke Barnicott. By William Howitr. And other Tales. Is. My First Cruise. By W. H. Kingston. And other Tales. Is.

The Boat Club. By Oliver Optrc. And other Tales. Is.

The Delft Jug. By Silverpen. And other Tales. is. 


\section{Shilling Story Books-(continued).}

The Flchester College Boys. By Mrs. Henry Wood. And other Tales. xs.

The Little Peacemaker. By Mary Howitr. And other Tales. Is.

The Secret Society. By Mrs. De Morgan. And other Tales. Is.

Shilling Toy-Books. In Demy 4to, stiff covers. With full-page Illustrations printed in Colours by KRONHEIM.

1. How Cock Sparrow Spent his Christmas.

2. The Adventures of Robinson Crusoe.

3. Queer Creatures, Drawn by One of Themselves.

4. सॄsop's F'ables. (2I Plates.)

Steam Engine. By Galbraith and Haughton. Cloth, lettered, 3s. 6d.

Stock Feeder's Manual, The. The Chemistry of Food in relation to the Breeding and Feeding of Live Stock. By Dr. Cameron. Cloth, lettered, $5 \mathrm{~s}$.

Swiss Family Robinson. Done in Words of One Syllable, by the Author of "The Boy's First Reader." With Coloured Illustrations after Designs by GrISET, CRANE, \&c. Cloth, lettered, 3s. 6d.

Technical Series, consisting of a series of Two Shilling Volumes, which contain all the essentials of a Technical Education, the principles of Science and Art being laid down with every possible clearness, and their practical application to the various branches of skilled workmanship being remonstrated and illustrated so as to enable any one of ordinary intelligence to avail himself of the advantages which a technical education is calculated to confer upon the well-instructed artisan.

The following Volumes of the TECHNICAL SERIES are now ready:-

Iinear Drawing. By Erlis A. Davidson. Lecturer on Engineering and Architectural Drawing in the City of London Middle Class Schools, contains the principles of Linear Drawing as adapted to Trade, Manufactures, Engineering, Architecture, and Design, with about r5o Illustrations, ard six whole page diagrams of working drawings. Cloth, limp, $2 s$.

Orthographic and Isometrical Projection. by the same Author, treats of the Projection of Plans, Elevations and Sections of Solids, and the Development of Surfaces. for Masons, Carpenters, Builders, Architects, Metal-Plate Workers, Plumbers, and Artisans generally. Illustrated with about 40 whole page diagrams, drawn on Wood by the Author. Cloth, limp, 2s.

Linear Drawing and Projection. The Two Volumes in One. Cloth, lettered, 3s. 6d. 


\section{Technical Series-(continued).}

Building Construction, the Elements of, and Architectural Drawing, with 130 Illustrations drawn on Wood by the Author. By Ellis A. Davidson, Author of "Linear Drawing," "Projection," "Right Lines," \&c. Cloth, limp, 25.

: Systematic Drawing and Shading. By Charles Ryan, Head Master, Leamington School of Art. Cloth, limp, 2s.

Drawing for Joiners and Carpenters. (In the Press.)

Thorwaldsen's Triumphal Entry of Alexander the Great into Babylon. Twenty-two Plates, Folio. With Descriptive Le terpress, and Essay on. "The Personal and Art Character of Thorwaldsen," by Hermann Lucke. 42s.

Travels, Illustrated : a Record of Discovery, Geography, and Adventure. Edited by H. W. BATES, Assistant-Secretary of the Royal Geographical Society, and profusely Illustrated by the best Artists of the day from drawings made on the spot. Royal 4to, cloth, lettered, I5s. Extra cloth, full gilt, gilt edges, 18s.

Two Shilling Series of New and Original Works. Bound in best cloth, gilt edges, with Coloured Illustrations.

Beatrice Langton; or, The Spirit of Obedience. 2s.

New Stories and Old Legends. By Mrs. T. K. Hervey. With Illustrations printed in Colours. Cloth, gilt, 2S.

Owen Carstone: a Story of School Life. With Illustrations printed in Colours. Cloth, gilt, 2s.

The Boy. who Wondered. By the Author of "Ups and Downs in an Old Maid's Life. 2s.

The Little Orphan. Coloured Illustrations by KRonнeim. Cloth, lettered, 2 .

The Story of Arthur Hunter and his First Shilling. 2s.

The Story of the Hamiltons. With Illustrations printed in Colours. Cloth, gilt, $2 \mathrm{~s}$.

The Hillside Farm. Cloth, gilt, 2 s.

Tyndall's Natural Philosophy, in Easy Lessons. Cloth, lettered, 2s. 6d.

Vegetable Physiology, in a Series of Easy Lessons, by Dr. L.ANKESTER, Author of "Popular Lessons on Food." Illustrated. Cloth, is. 6d.

Webster's Etymological Dictionary. The Etymology of every Word given, and a Vocabulary of the Roots of Words. Cloth, 3s. 6d.

What Shall My Son Be? A Handbook of the Professions. By Francis Davenant. Cloth, 7s. 6d. 
World of the Sea. Translated from the French of ALFRED Frenol, by the Rev. H. M. Hart. Demy 8vo, with Coloured and Tinted Plates, and numerous Wood Engravings. Best cloth, lettered, 2 Is.

World of Wonders, The. A Record of Things Wonderful in Nature, Science, and Art. Cloth, 7s. 6d. ; full gilt, ros. 6d.

Wonders, Library of. A Series of Gift Books, handsomely printed, illustrated, and bound. Cloth extra, each $5 \mathrm{~s}$.

Wonders of Intelligence in Animals.

Wonders of Architecture.

Wonders of Bodily Strength and Skill.

Wonderful Balloon' Ascents.

(Other Volumes are in preparation.)

The following CATALOGUES of Messrs. CAsseld, Petter, and Galpin's Publications, \&c., are now ready, and may be had from any Bookseller:-

1. Catalogue of Educational Works, of Students' and Scholars' Materials.

2. Catalogue of Magazines and Serial Publications.

3. The Doré Vignette Catalogue.

4. The Children's Books Catalogue, Illustrated. Rewards and Prizes.

5. The Complete Descriptive Catalogue.

6. Classified Catalogue of 60,000 Electrotypes of Valuable Engravings for Sale. 


$$
\text { . }
$$

5

$=$ 



\section{.}


(1) 